\title{
Regional correlations across the Internides-Externides front (northwestern Rif Belt, Morocco) during the Late Cretaceous-Early Burdigalian times: palaeogeographical and palaeotectonic implications
}

\author{
KH. EL KADIRI ${ }^{1}$, R. HLILA ${ }^{1}$, C. SANZ DE GALDEANO ${ }^{2}$, A. C. LÓPEZ-GARRIDO ${ }^{2}$, \\ A. CHALOUAN ${ }^{3}$, F. SERRANO ${ }^{4}$, A. BAHMAD ${ }^{5}$, A. GUERRA-MERCHÁN ${ }^{4} \&$ \\ H. LIEMLAHI ${ }^{1}$ \\ ${ }^{1}$ Université Abdelmalek Essaadi, Faculté des Sciences, Dep. Geology, BP 2121, 93003 Tetuan, \\ Morocco (e-mail: khkadiri@fst.ac.ma) \\ ${ }^{2}$ University of Granada, Facultad de Ciencias, Dep. Geodinamica, Av. Fuente Nueva, \\ 18002 Granada, Spain \\ ${ }^{3}$ Université Mohammed V-Agdal, Faculté des Sciences, Dep. Geology, BP 1014, \\ 10000 Rabat, Morocco \\ ${ }^{4}$ University of Malaga, Dep. Ecologia \& Geologia, Teatinos, Malaga, Spain \\ ${ }^{5}$ Société Nationale d'Etudes du Détroit de Gibraltar (SNED), 31 r. Al Alaouyines, \\ Rabat, Morocco
}

\begin{abstract}
New insights into the palaeogeographical evolution of the Rifian Internides and their external surroundings are inferred from six key stratigraphic successions selected across the Internides-Externides front. These successions span a time interval ranging from the late Cretaceous to the early Burdigalian. The main results are: (1) important lost palaeogeographical domains should be located during the late Cretaceous-Eocene between the present-day Ghomarides and the Dorsale Calcaire, on one hand, and between the Predorsalian units and the Flysch Trough as isolated carbonate platforms, on the other hand; (2) during the late Eocene-early Oligocene an extensional tectonic event, well marked in the Dorsale Calcaire, caused the collapse of these platforms and resulted in olistostromes and coarse-grained breccias in both the Predorsalian and the Béni Ider areas; (3) by the beginning of mid-Oligocene, an overturning contractional event in the Ghomarides resulted in the regional onset of the siliciclastic depositional regime throughtout these palaeogeographical areas; (4) during the Aquitanian-early Burdigalian, the stepwise return of pelagic deposition in the Ghomarides indicates extensional phases, whereas the homogenization of the same pelagic facies over the Dorsale Calcaire and its external surroundings may indicate that the previously distant palaeogeographical areas were brought nearer (i.e. just before large-scale thrusting).
\end{abstract}

The Gibraltar arc consists of two juxtaposed structural domains: (1) the Internal Domain, (Internides) where the orogenic contractions started from Oligocene time and generally resulted in high-grade metamorphism, particularly in its innermost part; (2) the External Domain (Externides), where the outward migrating orogenic contractions during Miocene time progressively produced piggyback-foredeep basins and ramp-anticline structures. The culmination of these phenomena during the paroxysmal phase resulted in a high accretionary prism and successive large-scale gravitational processes (Chalouan et al. 2006).

The Tertiary sedimentary filling within and/or close to these forming basins was differently interpreted in both domains. Whereas there is acceptance that the filling of the main flysch depocentres in the External Domain occurred shortly before the paroxysmal nappe emplacement, or even as syntectonic deposits, competing hypotheses were presented for the equivalent strata in the Internal domain. Some workers attempted to link them to postorogenic deposits transgressively sealing the paroxysmal structures (e.g. Durand-Delga et al. 1993), whereas others considered them as recording a near-continuous marine regime entirely predating the main orogenic events (e.g. Maaté 1996). Recently, detailed stratigraphic studies of the Oligo-Miocene cover were carried out in the Malaguides (Guerrera et al. 1993; Martin-Martin et al. 1997) and the Ghomarides (Feinberg et al. 1990; El Kadiri et al. 2000, 2001). They showed that the 
Oligo-Miocene sedimentary cycles were episodically induced by extension-related marine encroachments punctuating contractional events during a polyphase tectonic scenario (Comas et al. 1992; Garcia-Dueñas et al. 1992; Chalouan et al. 1997).

The aim of this paper is to extend this approach to time-equivalent depositional series belonging to both sides of the Internide-Externide front (i.e. the Dorsale Calcaire, Predorsalian and Béni Ider series). Some of the studied series are newly dated and/or described herein. Good examples are provided by: (1) the Dradia-El Onzar and Talembote sections in the Ghomaride Domain; (2) the Hafat Srir section in the Dorsale Calcaire; (3) the wellexposed Tamezzakht succession (located in the Predorsalian zone) that belongs to this frontal zone, to which special attention will be paid here. Its extended time-range (from the late Cretaceous the early Burdigalian), gravity-flow events, and welldelineated discontinuities are used to monitor regional-scale correlations across the InternalExternal Domains (see El Kadiri et al. 2005, for detailed sedimentological data).

The general interest of this approach is to promote the correlation between the internal and the external zones in deciphering the tectonic and/or eustatic significance of their coeval deposits. Thus, these two domains can no longer be taken as two independent geological realms when reconstructing the tectonosedimentary evolution of the Gibraltar arc evolution.

\section{Geological background}

The Rifian Internal zones (Fig. 1) consist of a complex nappe pile resulting from the westwardvergent stacking of three distinct units: the Sebtides, Ghomarides and the Dorsale Calcaire.

The Sebtides consist of varied metamorphic nappes, including a granulitic-mantle ultramafic unit, which is underlain (Sebta massif) and overlain (Béni Bousera massif) by gneiss and schists of upper-crustal affinities. These in turn are overthrust or are overlapped by detached high-pressurelow-temperature metapelitic strata, mainly of late Palaeozoic-Triassic age (Federico units; Bouybaouène et al. 1995), a fact that supports the attribution of the Sebtide nappe emplacement to the Alpine orogeny. The ultramafic rocks of Béni Bousera essentially consist of spinel-bearing

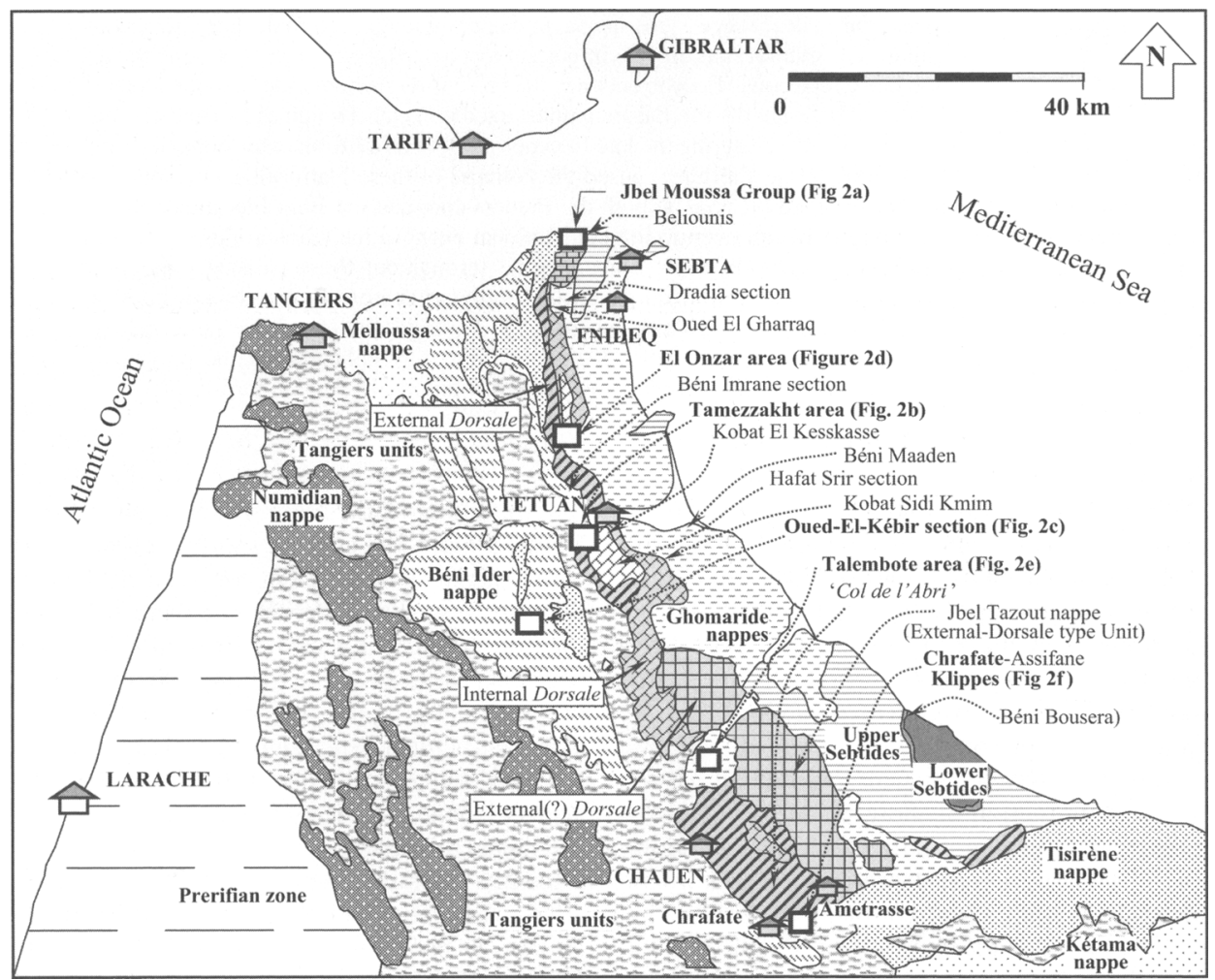

Fig. 1. Geological map of the northwestern Rif belt and location of the study areas (see Fig. 2 for details). 
lherzolites. They were interpreted as a hot asthenospheric dome (Loomis 1975; Platt \& Vissers 1989) or conversely as pre-Alpine slivers uprooted from Precambrian infracrustal levels and emplaced in the upper crust (Kornprobst 1974). Integrated approaches including detailed structural field-survey (Reubert et al. 1982; Saddiqi et al. 1988) and geochronological analyses (Sanchez-Rodriguez \& Gebauer 2000) showed that the lower Sebtide lherzolites were initially derived from a lithospheric mantle, and were subsequently emplaced as tectonic slivers within upper crustal levels. This scenario occurred in two main stages, during Tethyan rifting at about 183-131 Ma, and during Palaeogene subductioncollision (Chalouan et al. 2001; Michard et al. 2002). Geochemical data (Targuisti 1994), and even the stratigraphic record (El Kadiri et al. 1992, 1995), support the idea that the Béni Bousera-Ronda peridotites derived from an asthenospheric dome, the ascent of which started as early as Mesozoic time (SanchezRodriguez \& Gebauer 2000). The conditions and kinematics of their final exhumation as well as of that of the surrounding metamorphic rocks are still a matter of debate (see, for example, the discussion by Balanya \& Garcia-Dueñas 1987; Lonergan \& White 1997; Azañon et al. 1998; Morales et al. 1999; Azañon \& Crespo-Blanc 2000; Calvert et al. 2000).

The Ghomaride nappes (Kornprobst 1974; Chalouan 1986) generally thrust the Sebtides. They mainly consist of Palaeozoic schists, which compositionally resemble their Hercynian homologues known at present in the eastern Moroccan Meseta (Chalouan 1986), a fact that supports a palaeogeographical reconstruction in which they originally derived from an eastern domain, where they formed the westernmost part of the "AlKa$\mathrm{PeCa}$ ' palaeoplate (Bouillin et al. 1986; Chalouan \& Michard 1990; Guerrera et al. 1993). Lithofacies, metamorphism and the position within the nappe pile allow four main nappes to be distinguished (Chalouan 1986; Chalouan \& Michard 1990).

The Dorsale Calcaire was first interpreted as corresponding to the Alpine Ghomaride cover (Durand Delga et al. 1962; Kornprobst 1974) detached from its Palaeozoic basement during Tertiary thrusting. However, characterization of an independent Mesozoic Ghomaride cover with respect to the carbonate Jurassic strata of the Dorsale Calcaire, on one hand (Maaté 1984, 1996; El Kadiri 1991; El Kadiri et al. 1992), and detailed stratigraphic analyses of the entire Mesozoic successions of both the Internal and the External Dorsale, on the other hand (Nold et al. 1981; El Kadiri 1984, 1991; Olivier 1984; El Hatimi 1991; Maaté 1996), led to the two latter being assigned to the palaeomargin bordering westwards and/or southwards the Rif 'Internal zones'. This result appears in accordance with the concept of a 'Predorsalian zone' (Didon et al. 1973) that palaeogeographically corresponded to the deepest part of this palaeomargin (e.g. Chrafate Klippes units, Assifane units, El Hatimi 1982; El Kadiri 1984; El Hatimi et al. 1988; Ben Yaïch et al. 1988). Triassic-earliest Jurassic, thick-bedded, shallow-water carbonate limestones make up the main massifs of the Dorsale Calcaire. They may be topped with polyphase palaeokarst surfaces in the Internal Dorsale (El Kadiri 1991; Maaté 1996) and with Fe-encrusted hardgrounds in the External Dorsale (El Kadiri 2002a,b).

In the Internal Dorsale, reduced pelagic series may diachronously onlap the massive carbonate formations. The most noteworthy of these are developed in rosso-ammonitico facies during the Domerian-Toarcian, and in Saccocoma- and/or Calpionella-rich mudstones during the TithonianBerriasian. A long-lasting palaeokarst history occurred in the intervening time span (El Kadiri 1991; El Kadiri et al. 1992), a feature that recalls the Mid-Late Jurassic 'Main Gap' found by Farinacci $(1996,2002)$ and Farinacci et al. (1997) in the Central Mediterranean Apennine areas. The most distinctive features of the External Dorsale are: (1) the rosso-ammonitico facies and cherty limestones, which can start as early as the Sinemurian (e.g. Arnioceras-rich strata, Fallot 1937; Griffon 1966); (2) the red and/or green radiolarites, the onset of which occurred as early as the LiassicDogger transition (El Kadiri 1984, 1991). For this reason, they were considered as being amongst the earliest continental-margin-related Jurassic, biosiliceous deposits in the Tethyan realm (De Wever et al. 1985). They continued until early Tithonian time (El Kadiri 1991).

In both Dorsale units, Cretaceous successions recorded important hiatuses during the Hauterivian-Albian pro parte and the early Senonian, the best characterized ones being the Campanian and Maastrichtian Globotruncana-rich marly mudstones referred to as 'Capas Rojas' and 'Capas Blancas', respectively (El Kadiri 1991). Palaeogene successions consist of: (1) thin nodular black shales of Paleocene age; (2) variegated marl-nummulitic sand alternations of Eocene-mid-Oligocene age (Griffon 1966; Raoult 1966; Nold et al. 1981; Maaté et al. 1993; Hlila 1994, 2005; Maaté 1996); (3) micaceous rustcoloured sandstones, during the late Oligocene(?)early Aquitanian.

Tectonically, the fact that the latter deposits are considered as being the youngest strata trapped between different slices (Nold et al. 1981) suggested a first phase of thrusting during the Aquitanian. Later, characterization of early Burdigalian marine strata involved in both the internal and external fronts of the Dorsale Calcaire (Feinberg \& Olivier 1983; Ben Yaïch et al. 1986; Feinberg 

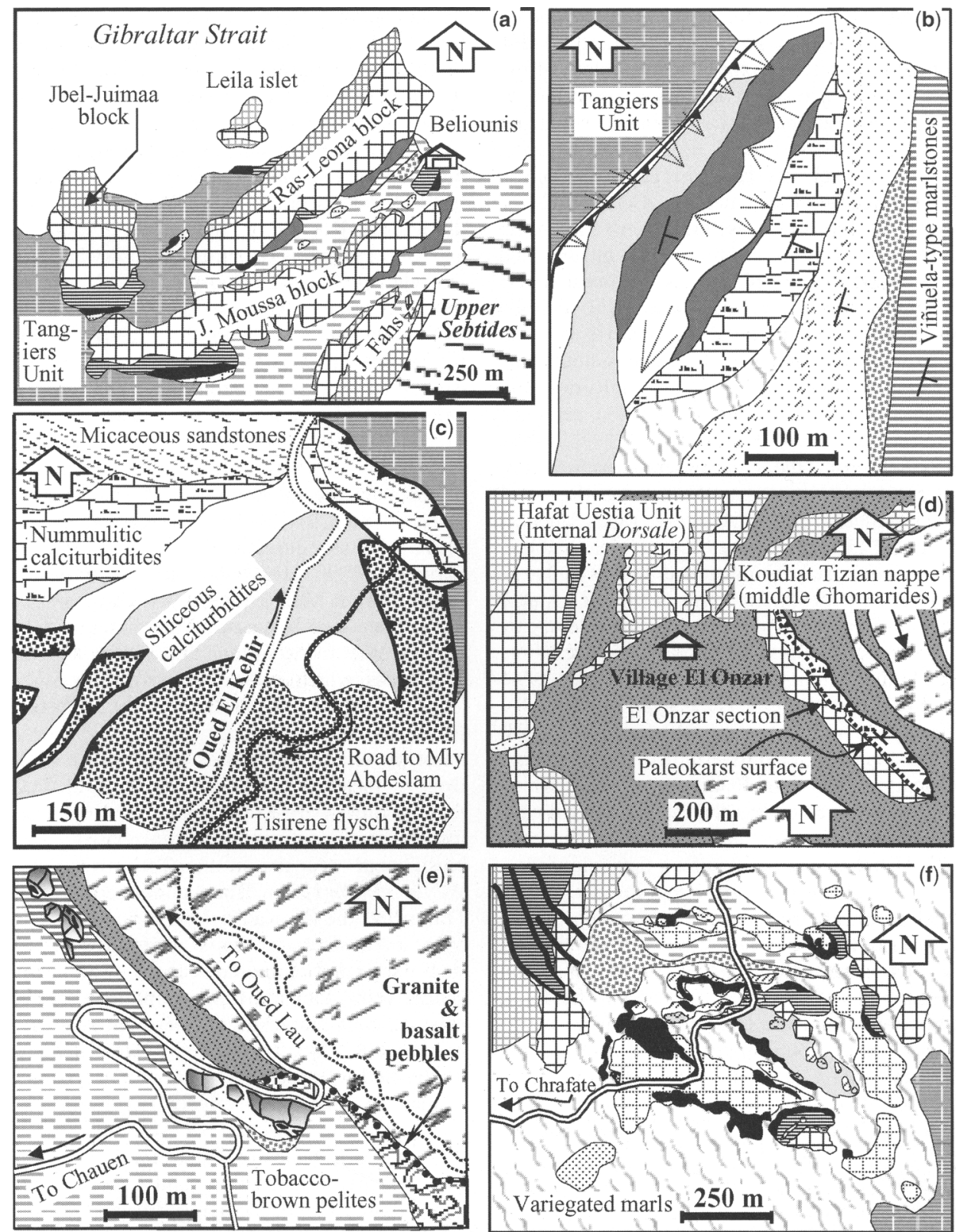

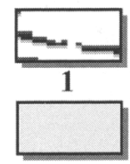

11

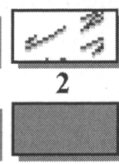

12

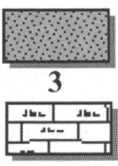

13

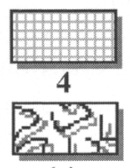

14

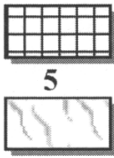

15

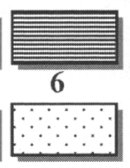

16

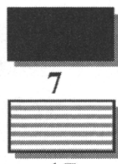

17

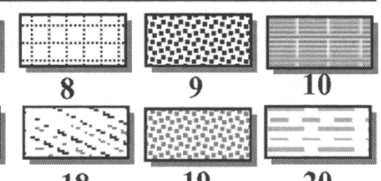

18

19

20

Fig. 2. Geological-structural setting of the areas including the investigated successions. (a) Jbel Moussa Group (modified from Komprobst \& Durand Delga 1985); (b) northern part of the Tamezzakht sector (this work); (c) main lithological components of the Mauretanian series cropping out the vicinity of the Oued-El-Kébir in the Béni Ider area (simplified from Didon 2006); (d) example of a residue of the karstified Ghomaride carbonate cover close to the Internal Dorsale (El Onzar succession, simplified from Raoult 1966); (e) Ghomaride siliciclastic cover in the Talembote area (simplified from El Kadiri et al. 2001), (f) western Chrafate Klippes, a good example of the Predorsalian olistostromes 
et al. 1990; El Kadiri et al. 2001) led researchers to envisage a second phase, during which the whole Dorsale nappe pile underwent large-scale thrusting before being trapped between the Ghomaride terranes and the flysch-nappe domain. In some segments (Haouz chain), the latter event resulted in a double 'encapuchonnement' process (e.g. Raoult 1966; Hlila 1994, 2005), a kinematic scenario that explains the backthrusting and related fan-shaped structures.

The northern part of the Rif calcareous chain (Dorsale Calcaire) is occupied by the Jbel Moussa Group, which is dominated by four kilometre-scale juxtaposed tilted blocks (J. Moussa, J. Juimaa and Ras Leona and Leila) of a Jurassic continental passive palaeomargin (El Kadiri et al. 1990; El Hatimi 1991). All these blocks exhibit Triassic-early Cretaceous successions that strongly recall the Spanish Penibetics (Fallot 1937; El Hatimi 1991), the Gibraltar and Los Pastores massifs (Durand Delga \& Villiaumey 1963), and/or the Southern Middle Subbetics (El Kadiri et al. 1990). The fact that the J. Moussa Group is thrust directly over the Tangiers units and its Spanish equivalents (Gibraltar and Pastores, both occurring in the external Campo de Gibraltar area), led Durand-Delga (1972, p. 274) to assign all these calcareous blocks to an external 'Cretaceous cordillera' separating the Mauretanian and the Massylian basins. This palaeogeographical setting proved to be identical to that proposed by Raoult (1974) for the Algerian 'Prekabyle basement'. Concurrently, Didon et al. (1973) defined the Predorsalian units as corresponding to a narrow basin externally bordering the Dorsale Calcaire units. It is noteworthy that the Predorsalian zone was characterized by the Aquitanian Numidian-like sandstones (the so-called 'Beliounis sandstones'), which were fundamentally defined in the J. Moussa Group itself. Thus, this Group implicitly bears the double definition of a
Predorsalian zone and an external ridge. The 'Tariquide Ridge' is herein used in the strict sense of a high palaeogeographical zone delivering shallowwater carbonate material (calciturbidites) to both the Predorsalian and the Mauretanian trough during the late Cretaceous-early Oligocene.

The External zones are dominated by large-scale 'parautochthonous' terranes (the Tangiers, Ketama and Loukous units, mainly), and their overriding sandstone-flysch nappes. These in turn may thrust each other along well-delineated parallel structures, which act as the topographical lines of the Gibraltar arc. Although palaeogeographical reconstructions of the External zones still remain a subject of debate, especially for the Mesozoic, there is agreement that their tectonosedimentary evolution during the Tertiary was primarily conditioned by piggy-back basins and ramp-anticline structures, both generated by deep detachment planes (e.g. Morley 1987, 1988, 1992; Ben Yaïch 1991).

Close to the internal border, the External Domain (the so-called Intrarif) was strongly deformed so that its parautochthonous units locally show schistosity (Andrieux 1971; Frizon de Lamotte 1985) and the flysch successions were totally uprooted. The deformation style is predominantly characterized by duplex structures and imbricate slices.

Stratigraphic reconstructions carried out mainly by Durand-Delga (1972) and Durand Delga \& Didon $(1984 a, b)$ led researchers to recognize the two main flysch successions previously defined in the Kabylian domains (Bouillin et al. 1970): (1) the Mauretanian series, which includes in its lower half the Tisirène early Cretaceous calciturbidites and holoquartzous sandstones, and in its upper half the Béni Ider late Cretaceous-Aquitanian calciturbidites and micaceous sandstones; (2) the Massylian series, which may encompass in a single stratigraphic column the Barremian-Albian olive-green sandstone flysch (Massylian sensu

Fig. 2. Continued. (simplified from El Kadiri 1984). 1, low-grade-metamorphosed Triassic strata (Federico units, upper Sebtides); 2, Palaeozoic schists; 3, Verrucano-type Triassic red sandstones; 4, late Triassic dolomites; 5, earliest Liassic massive limestones; 6, mid- to late Liassic pelagic successions (cherty limestones and/or rosso-ammonitico facies); 7, mid- to late Jurassic red radiolarites; 8, latest Tithonian-Berriasian Aptychus-bearing calciturbidites; 9 , Aptian-Albian, thick-bedded, fine-grained sandstones (Tisirene flysch); 10, carbonate-poor, green pelites (Tangiers units, Campanian-Maastrichtian mainly); 11, Campanian-Maastrichtian (mainly) calciturbidites of the Mauretanian series and the Chrafate Klippes; 12, Microcodium-bearing Paleocene calcarenites; 13, Nummulite-rich, white massive grainstones (El Onzar succession, (d)) and calciturbidites (Tamezzakht and Oued-El-Kébir areas; (b) and (c), respectively); 14; late Oligocene chaotic mixture of the Talembote area, reworking Triassic strata, with a basal coarsegrained conglomerate rich in granite and basalt pebbles; 15, latest Eocene-mid-Oligocene variegated marls with largescale olistoliths, particularly in the Predorsalian zone; 16, late Oligocene-Aquitanian yellow soft marls with largescale olistoliths inherited from Triassic and Eocene massive carbonates (Tamezzakht and Talembote successions, (b) and (e), respectively); 17, early Burdigalian Viñuela-type green pelagic marlstones with similar large-scale olistoliths (in Tamezzakht and Talembote areas); 18, late Oligocene-early Burdigalian micaceous sandstones (the so-called 'Béni Ider' Flysch); 19, late Oligocene-Aquitanian holoquartzose yellow sandstones (the so-called 'Beliounis' sandstones); 20, early Burdigalian, carbonate-poor, tobacco brown pelites and holoquartzose tobacco brown channelized sandstones (Talembote and Chrafate Klippes). 
stricto) and the late Oligocene-Aquitanian Numidian sandstones. However, in the latter case upper Cretaceous transitional strata are not yet clearly characterized.

On the whole, these flysch series were used to define the Maghrebian 'Flysch Trough' (Didon et al. 1973; Bourgois 1978; Durand-Delga 1980; Martin-Algarra 1987), along which the Mauretanian flyschs were located, close to the $\mathrm{AlKaPeCa}$ palaeomargin (Bouillin et al. 1986). In contrast, the Massylian flyschs were located close to the African palaeomargin (e.g. Raoult 1974). In the Rif domain the latter palaeomargin is represented by the Jurassic terrigenous series (mainly 'Ferrysch' successions, Wildi 1981) known in the Mésorif and Prérif zones (e.g. compiled data of Ben Yaïch 1991; Benzaggagh 1996).

On the basis of the stratigraphic data given below, we shall see that the Flysch Trough can no longer be considered to be formed by a single, large-scale homogeneous basin, as the existence of external isolated platform(s) subdivided it into at least two elementary basins (see also El Kadiri et al. 2003).

\section{Stratigraphic framework of the selected successions}

Six study areas (Fig. 2) have been selected from the principal domains known in the Internal zones and the surrounding External ones, namely the Ghomarides, the Dorsale Calcaire, the 'Tariquide Ridge' and the Flysch Trough. Their stratigraphic successions are thoroughly reassessed (Fig. 3) and their possible juxtaposition during the early Burdigalian is outlined to better assess the sources of the carbonate clastic material. The Tamezzakht succession appears to be the most complete, as it spans a wide time-interval ranging from the latest Cretaceous to the early Burdigalian. Thus, it provides a rare opportunity to appraise a long-term tectonosedimentary evolution through a single stratigraphic column.

\section{In the Ghomaride domain}

The El Onzar and Dradia successions (Figs 2d and 3 ) crop out close to the Ghomaride-Dorsale boundary in the northernmost part of the Ghomaride domain, north of the city of Tetuan. They provide some of the best evidence known for the Ghomaride Eocene cover. In addition to the lithostratigraphic description and dating controls given by several workers (e.g. Raoult 1966; El Kadiri et al. 1992; Maaté 1996) and completed herein, we have found two complex discontinuity surfaces in these successions, at the very base of the Eocene strata and at their top.
In both outcrops, white nummulitic sandstones and Nummulite-rich massive grainstones rest on early Liassic white massive limestones after a conspicuous palaeokarst discontinuity (palaeokarst surface 1, Figs 2 and 3). This may indicate that the Ghomaride terranes experienced a protracted emersion history during the Mesozoic-Paleocene, resulting in the near-complete removal of their carbonate cover.

The stratigraphic top of the nummulitic white limestone bar $(10-30 \mathrm{~m})$ in turn shows an important palaeokarst surface (palaeokarst surface 2, Fig. 3). In some cases (El Onzar succession), karstic relief (small-scale kamenitzas and palaeosinkholes) is filled with red to brown sandstones made up of the 'en-echarde'-type quartz, which originated from pedological processes (Meyer 1987). An algal-Discocyclina-rich grainstone bed $(0.10-1 \mathrm{~m})$ transgressively rests on the palaeokarst surface. It is generally capped with a remarkable Fe-crust (Fe-HG, Fig. 3), from which bacteriaproduced Fe-epigenesis processes (e.g. Préat et al. 2000; El Kadiri 2002a) may extend several decametres downwards into the host rock, which becomes rust coloured. Outcrop survey shows that this Fe-crust also may directly cap the underlying nummulitic bar when the transgressive Discocyclina-rich deposition is laterally lacking, as occurs in many transgressive deposits (e.g. lag gravel of Plint (1988), transgressive lag deposit of Fürsich et al. (1991), transgressive lags of Burkhalter (1995) and hiatal shell concentrations of Rivas et al. (1997), among others). Thus, the double discontinuity (palaeokarst $+\mathrm{HG}$ ) at the top of the nummulitic bar may best be classified as a rock-ground surface in the sense of Clari et al. (1995).

Dating controls based on benthic Foraminifera lead us to assign the stratigraphic top of the nummulitic bar to the late Lutetian (e.g. Raoult 1974; see also Table 1, sample ONZ 5).

Yellow to rust-coloured marls ( $20-30 \mathrm{~m}$ ) sharply overlie the Fe-hardground surface. In their upper half they contain fine-grained sandstone intercalations, which progressively dominate the depositional regime (see the possible interpretation below). They yield planktonic Foraminifera indicating a latest Lutetian-Early Bartonianage (Table 1, sample ONZ 10)

In the Talembote area (Fig. 2e) located $40 \mathrm{~km}$ south of the city of Tetuan close to the InternideExternide front, decametre-scale sedimentary klippes are embedded within an Aquitanian-early Burdigalian siliciclastic matrix (Fig. 3). They exhibit an identical Liassic-Eocene stratigraphic succession with the same discontinuities and lithological components, and their presence here may have an important bearing on the palaeogeographical reconstructions (see below). 


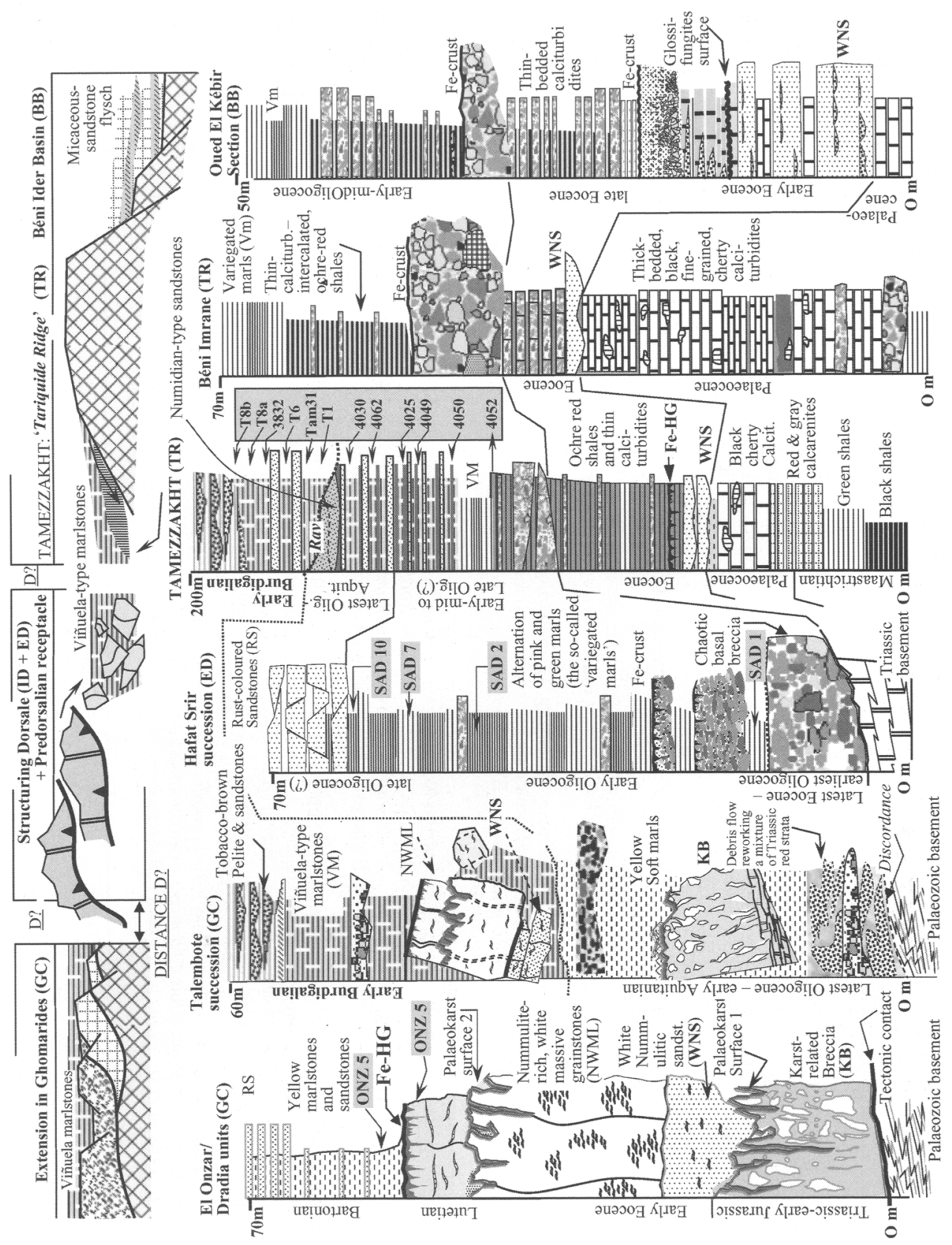

Fig. 3. Stratigraphic correlation of the studied successions, selected from distinct domains of the northwestern Rif belt: the Ghomaride domain (Dradia-El Onzar units, Talembote succession), the (Calcareous) Dorsale Calcaire (Hafat Srir succession) of the Internal zones; the Predorsalian fringe (Béni Imrane succession), and the Béni Ider area (Oued-El-Kébir section) of the External zones (see text for details). The upper part of the figure tentatively proposes a possible reconstruction of this scenario during the early Burdigalian, i.e. just before the orogenic paroxysm (the shortening distance D? remains uncertain). Grey shading indicates the sampling levels from which new biostratigraphic dates are given in Tables 1 and 2 . 
KH. EL KADIRI ET $A L$.

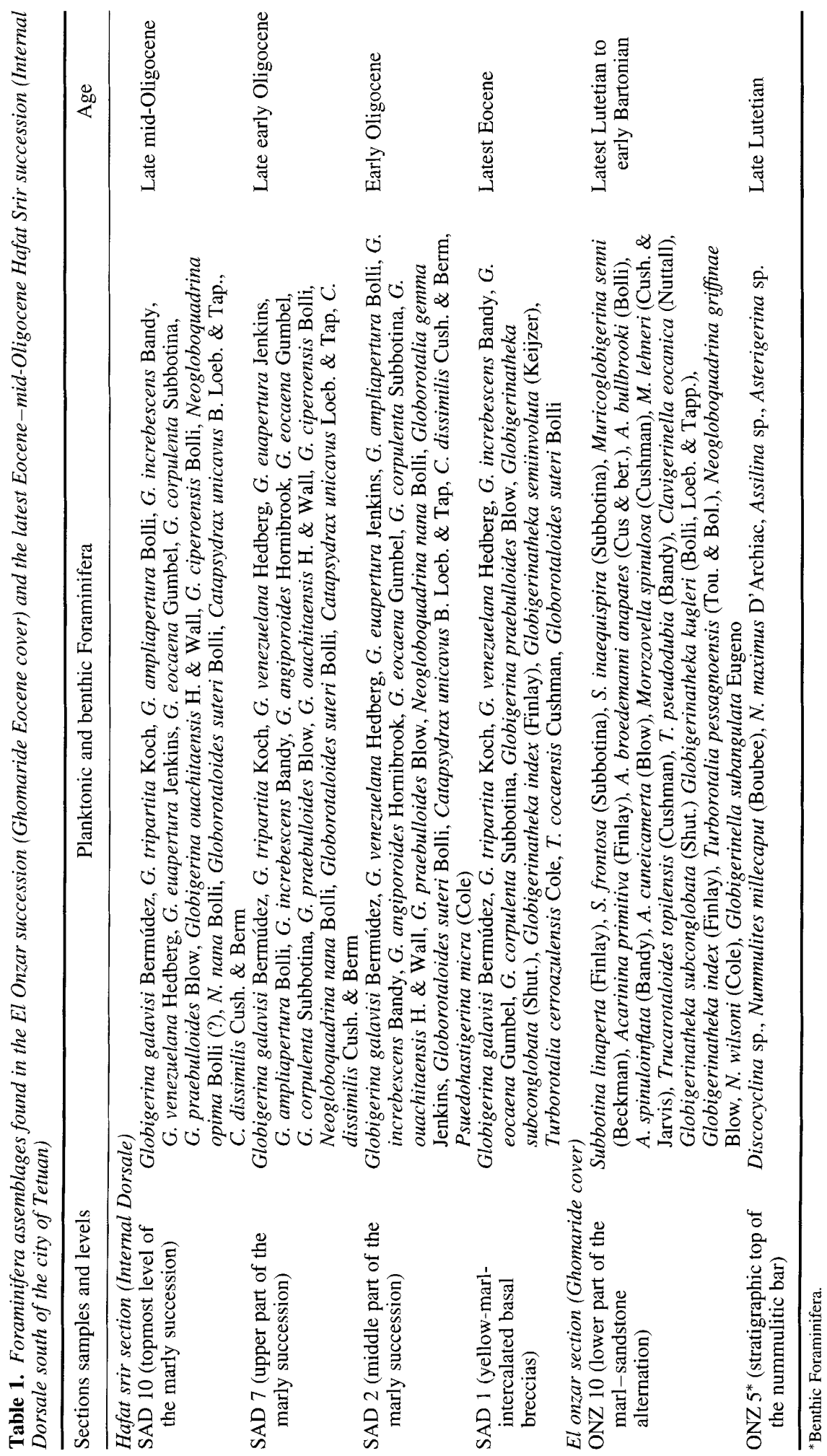


The most noteworthy feature of the Talembote Tertiary succession is the facies contrast, which is well marked in the field, between its four sedimentary formations ranging from the late Oligocene to the early Burdigalian (El Kadiri et al. 2001, and Fig. 2e). For regional correlation, it is relevant to note the sharp facies change from the yellow soft marls of the second formation (latest OligoceneAquitanian pro parte) to the green pelagic marlstones of the overlying third formation (earliest Burdigalian). The former facies is particularly rich in planktonic Foraminifera (El Kadiri et al. 2001) and contains in its upper half spaced intercalations of yellow Alozaina-type sandstones, a facies widespread in the Aquitanian Malaguide cover and that of the northern part of the Ghomaride terranes. The second contains siliceous horizons and strongly recalls the Viñuela-type pelagic deposition (El Kadiri et al. 2001).

Various coarse-grained breccia flows are intercalated within the Talembote pelagic successions. All exhibit the same mixture of carbonate and metamorphic clastic material, with the ubiquitous Nummulite-rich and reefal boundstone blocks derived from a lost Palaeogene carbonate platform. Also ubiquitous are granitic and alkaline-basalt pebbles. The former were discovered in situ within the Carboniferous Marbella conglomerates, from which they are presumed to have been derived. In contrast, the origin of the alkaline basalts still remains unclear.

In the Internal zones of the Betic Cordillera, the coeval early Burdigalian Las Millanas-Viñuela Formation contains a basal conglomerate exhibiting the same clastic mixture. This may indicate that the source of supply was the same and had a wide palaeogeographical extent. Otherwise, it is relevant to note the presence, within the Spanish early Burdigalian conglomerates, of almost unaltered blocks and pebbles of the usual AlpujarrideSebtide facies, namely peridotites and garnet gneiss. Such pebbles have not yet been discovered in the Ghomaride cover.

\section{In the Dorsale Calcaire}

In the Dorsale Calcaire the most pronounced discontinuity is delineated by the widespread late Eocene-early Oligocene Breccias Nummuliticas (Nold et al. 1981) that independently rest on normal-fault-denuded Triassic or Jurassic strata, which pinpoint a regional extensional event. The Hafat Srir section, cropping out in the northern part of the Internal Dorsale (south of the city of Tetuan), provides a good example of this: it starts with a $5 \mathrm{~m}$ thick, ungraded, coarse-grained nummulitic breccia bed (facies R1 of Lowe 1982; facies F3 of Mutti 1992) that directly reworks pedologically pre-altered, rust-coloured Triassic dolomites. This basal breccia passes up into a thinning-upward alternation (c. $150 \mathrm{~m}$ thick) of pelagic marls and graded breccias. Well-developed Fe-crusts carpet near all the basal breccia beds. Yellowish pelagic marls, between them, yield planktonic Foraminifera indicating a latest Eocene age (Table 1, sample SAD 1). The overlying marly succession, which spans the early to mid-Oligocene interval (Maaté et al. 1993; Table 1, samples SAD 2, 7 and 10), comprises a rhythmic metre-scale alternation of carbonate-rich green marls and carbonate-poor pink marls, a fact that may be ascribed to cycles related to the calcite compensation depth (CCD) fluctuation, redox and/or productivity (Eicher \& Diner 1991; Einsele \& Ricken 1991). The Hafat Srir marly alternation may satisfactorily be used to interpret the origin of the widespread early to mid-Oligocene 'variegated marls' as the result of reworking and mixing by slope processes of the same kind of cyclic deposits.

These marly deposits are sharply overlain, after an erosive surface, by micaceous, wood-debris-bearing, rust-coloured sandstones, probably of late Oligocene-Aquitanian age (Hlila 2005). The onset of this siliciclastic depositional regime may be ascribed to a second extensional event, as shown by numerous synsedimentary normal faults. In thin section the rust colour is proved to be due to the presence of a large amount of pre-rubefaction, palaeosoil-derived carbonate clasts together with white and black quartz grains.

\section{In the Predorsalian zone}

The most representative successions of the Predorsalian zone crop out in the well-studied Chrafate klippe area (Didon et al. 1973; Lespinasse 1975; Nold et al. 1981; El Kadiri 1984, 1991; Olivier 1984; Ben Yaïch et al. 1988) where the early Oligocene 'variegated marls' (Fig. 2f) form decametreto hectometre-scale sedimentary klippes, inherited from Dorsale-type lost units, and pass upward into late Oligocene-Aquitanian Numidian-like sandstones (i.e. Beliounis sandstones, Didon et al. 1973). These two stratigraphic components (olistostromes and sandstones) are separately known in the Internal domain and the External one, respectively. As part of this peculiar zone we would like to consider the Tamezzakht stratigraphic succession (Figs 1, 2b and 3), which also combines features separately known in the Internal domain and the External one. This succession displays in its lower half a late Cretaceous-early Oligocene calciturbidite-shale alternation, similar to that of the external Béni Ider series. In contrast, its upper half is chiefly made up of early to mid-Oligocene variegated pelagic marls and rust-coloured 
sandstones. The latter are developed in the same Dorsale-type facies (see Table 2 for dating controls). They pass upward into late Oligocene-early Burdigalian pelagic deposits made up of yellow marls-green marlstone couplets identical to those previously described in the early Miocene Ghomaride cover. In addition, the intercalation within the late Oligocene-Aquitanian levels of the Beliounistype sandstone facies supports the attribution of the Tamezzakht succession to the Predorsalian zone.

In thin section, the calciturbidite flows commonly reveal the presence of carbonate clasts, whose facies strongly recalls the Internal Dorsale Jurassic series, namely the shallow-water white massive grainstones (earliest Liassic) and the Calpionella-Saccocoma-rich mudstones (Tithonian-Berriasian). However, the interposition of the External Dorsale between the Internal one and the Predorsalian zone, on the one hand, and the proximal character of the calciturbidite discharges, on the other, lead us to suggest a distinct carbonate source with respect to the Internal domain. Palaeocurrent directions that we have measured on the bed surfaces of the calciturbidite interval are $\mathrm{N} 70^{\circ}-\mathrm{N} 80^{\circ}$, with the current flowing towards the internal zones (from WSW to ENE, i.e. from an external source). In the overlying siliciclastic interval the current direction is $\mathrm{N} 20^{\circ}-\mathrm{N} 60^{\circ}$, mainly $\mathrm{N} 30^{\circ}-\mathrm{N} 40^{\circ}$, flowing from SW to NE. Thus, the clastic material of the Tamezzakht succession could be sourced from an external lost terrane, a result that fits well with the 'Tariquide Ridge' hypothesis (Durand-Delga 1972) and recalls the Penibetic and/or Ultra-Internal Subbetic seamounts of the southern Betic Cordillera.

The most noteworthy feature of the Tamezzakht pelagic marly deposits (late Oligocene-early Burdigalian) is the rhythmic alternation of yellow soft marls and green marlstones. In the Ghomaride cover, both facies are strictly limited to the latest Oligocene-Aquitanian and the early Burdigalian, respectively.

\section{Surrounding External Domain}

Two Paleocene-mid-Oligocene successions with stratigraphic features similar to those previously described can be selected from the surrounding External Domain: the Béni Imrane succession, which crops out north of the city of Tetuan between the Predorsalian zone and the Tangiers unit, and the Oued-El-Kebir succession cropping out along the main river crossing the Béni Ider area, $25-30 \mathrm{~km} \mathrm{SW}$ of the city of Tetuan (Fig. 2c).

Black, thick-bedded cherty mudstones rich in small planktonic Foraminifera (Subbotina pseudobulloides (Plummer) and Planorotalites compressa (Plummer)) of Paleocene age make up the lower half of the Béni Imrane succession (c. $30 \mathrm{~m}$ ). They can be accompanied by a channelized, coarse-grained basal division, which reveals that the black mudstones came from up-slope pelagic muds. They are sharply overlain by $c .5 \mathrm{~m}$ thick, thin-bedded calciturbidites with the sandy fraction being rich in penecontemporaneous Nummulites of Eocene age. Hence, there has been an important environmental change affecting the source area across the Paleocene-Eocene boundary, from exporting plankton-dominated muds into producing and shedding shallow-water-rich bioclastic sands together with an important lithoclastic fraction deriving from its carbonate substratum. A channelized white, Nummulite-bearing sandstone bed (WNS, Fig. 3) occurs in the intervening the stratigraphic levels. The latter facies also appears at the very base of both the Eocene deep-sea calciturbidites of the Tamezzakht succession and the Eocene shallow-water, limestone bar of the Ghomaride cover, a result that suggests key strata of regional correlation potential (WNS, Figs 3 and 4).

A $3-5 \mathrm{~m}$ thick, coarse-grained, poorly graded conglomerate bed sharply overlies the calciturbidite interval. It is covered with an Fe-crust and probably pinpoints the same extensional event that resulted in the latest Eocene-early Oligocene chaotic breccias in the Internal Dorsale and the Tamezzakht succession. The Béni Imrane Palaeogene series ends with a shaly interval (most probably of early to midOligocene age, by comparison with dating controls obtained from Tamezzakht similar levels), made up in its lower half of ochre-red, lime-poor shales with thin intercalations of calciturbidites, and in its upper half of variegated marls.

The Oued-El-Kébir section exhibits the same lithostratigraphical features, particularly: (1) the WNS key strata; (2) the Fe-crust-capped, chaotic breccia overlying the Eocene calciturbidites; (3) the early to mid-Oligocene ochre-red shales, a facies well known in the remainder of the external Béni Ider area (the so-called 'flysch coloré').

Regardless of the relative palaeogeographical position of the Oued-El-Kébir section, the entire Palaeogene stratigraphic evolution outlined in the Internal domain and close to its border seems to have been strongly influenced by a neighbouring carbonate platform. By the beginning of the late Oligocene, the total disappearance of the clastic carbonate material was combined with the onset of the siliciclastic depositional regime. Thus, at that time, the supplying carbonate platform(s) was (were) probably destroyed and/or drowned under the siliciclastic accumulations. In both cases, the sharp contact between the early-mid-Oligocene calciturbidite-intercalated red shales and the late Oligocene sandstone-intercalated yellow marls may be regarded as a depth-equivalent of the 


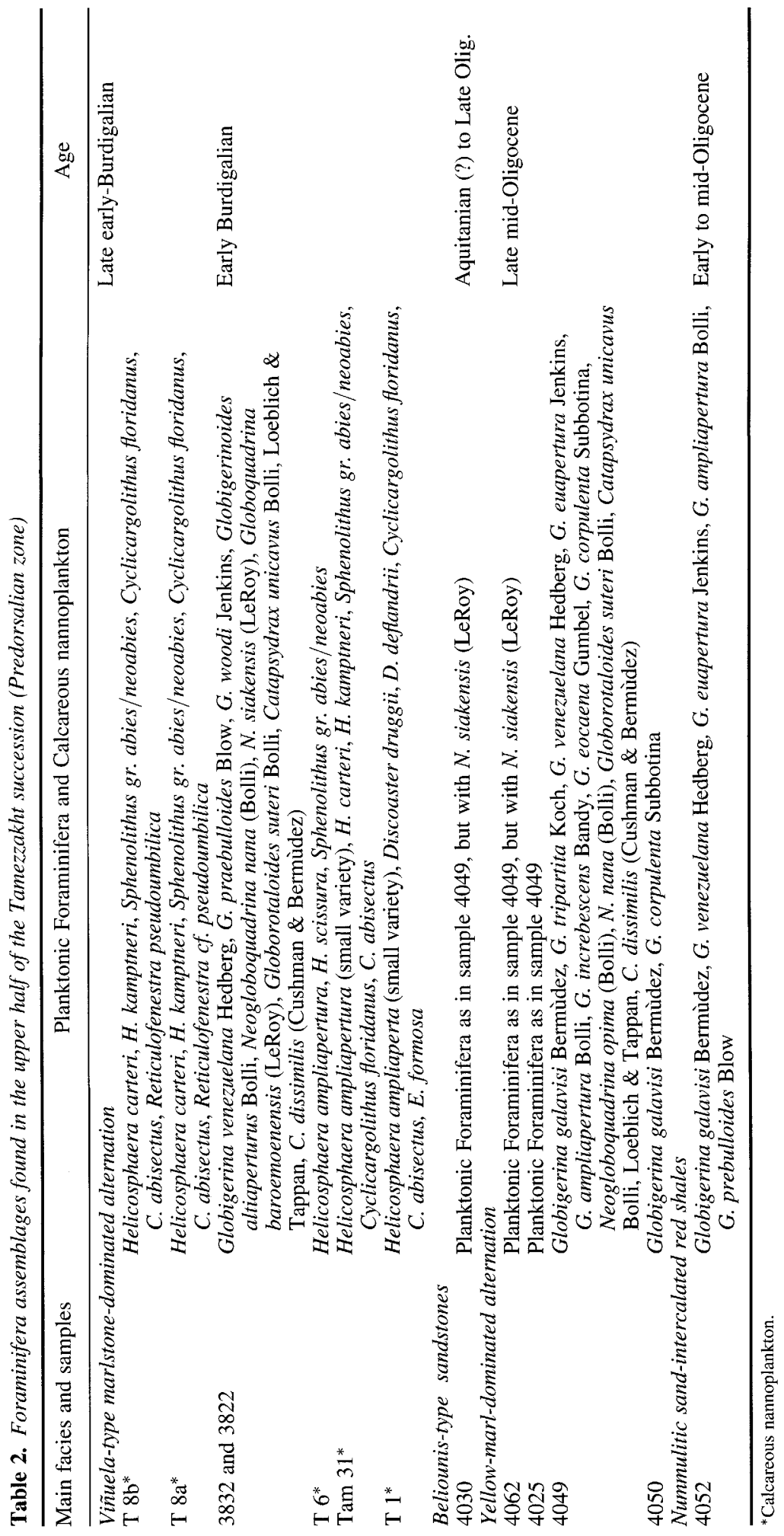


drowning-suffocation discontinuity in the sense of Schlager (1989, p. 7).

Petrographical evidence from the very base of the graded sandstone beds shows a mixture of basement-derived detrital fragments, namely, filonian-type quartz, schist, feldspar and micas. They are probably sourced from a tectonically raised, new source area(s). Regional correlations with both the External domain and the Internal one support such an assumption (see below).

\section{Discussion: regional correlations}

Figure 4 summarizes the facies contents of the palaeogeographical domains outlined in Figure 3, and highlights the recognized discontinuities (erosional, palaeokarstic and Fe-hardground-type surfaces) and the main calciturbidite and tectonosedimentary events. It should be noted that the Tamezzakht succession appears to be the most complete, with its facies being more clearly contrasted in the field (El Kadiri et al. 2005). Its position in a transitional area between the Internal domain and the External one makes it a useful starting point for regional correlations. From the latest Cretaceous onwards the main lines of comparison are described below (see also Fig. 3).

The latest Maastrichtian-early Paleocene pelagic-dominated strata (black shales and reduced ochre-red shales, facies 5 and 6 , respectively, Fig. 4) at the base of the Tamezzakht succession strongly recall their time-equivalent strata known in (1) the Dorsale Calcaire as Capas Blancas (facies 3, Fig. 4), made up of dark-coloured marl-limestone alternations (of Maastrichtian(?)Paleocene pro parte age, Griffon 1966; El Kadiri 1991); (2) the Jbel Moussa Group in the facies of ochre-red and black, lime-poor shales of lower Paleocene age (facies 6b, Ras Leona and Taoura sections, El Kadiri et al. 1990); (3) the southernmost External Dorsale ('Col de l'Abri' section, Nold et al. 1981; El Kadiri 1984) in the facies of variegated to ochre-red lime-poor shales of Maastrichtian-(?)Paleocene pro parte age (facies 4). In contrast, the Maastrichtian-Paleocene strata in the Béni Ider area are represented by thick packages of mixed carbonate-siliciclastic turbidites (facies 7 , El Kadiri et al. 2003), but within which intercalations of ochre-red lime-poor shales are a very common component.

The thick-bedded late Paleocene dark-coloured calciturbidites (facies 11) present a striking lithofacies analogue in the Béni Imrane area located $5 \mathrm{~km}$ NW of Tetuan, which may correspond to a lateral equivalent of the Tamezzakht succession. In the southern Dorsale Calcaire units Paleocene strata are generally poorly characterized and in most cases dating controls do not allow us to distinguish them from the underlying condensed late Cretaceous pelagic deposits or the overlying Eocene marly strata (Nold et al. 1981, p. 134). In its northern part, near the Kobat Sidi Kmim slice, a coarse-grained chaotic breccia (c. 15-20 m thick, facies 9) unconformably overlies a CampanianMaastrichtian Capas Rojas-Capas Blancas pelagic series (facies 1 and 3). Dark-coloured marls intercalated between the basal breccia flows contain planktonic Foraminifera of late Paleocene age (El Kadiri et al. 2003). The most conspicuous example of Paleocene gravity-flow events was found in the J. Moussa Group: as noted by El Hatimi (1991) and El Kadiri (1991), its largest elements, of up $1 \mathrm{~km}$ in length (Ras Leona and J. Moussa Blocks), are partly embedded within ochre-red and black shales of Late Maastrichtian-Paleocene age (facies 12). All these Paleocene chaotic breccia were probably linked to regional tectonic pulses, as they form also a widespread key stratum in the Kabylian domain (e.g. Raoult 1974). In many places throughout the northern Dorsale Calcaire (Haouz Belt), Raoult (1966) noted a Paleocene age for the Microcodium-bearing calcareous sandstones (facies 10, Fig. 4), which transgressively overlie the massive carbonate formations. Ben Yaïch et al. (1986) and Hlila (2005) described and dated in the Oued El Gharraq section an interesting dark-coloured glaucony-rich, bioclastic level ( $c$. $30 \mathrm{~cm}$, facies 8 ), which transgressively erodes late Cretaceous 'Capas Blancas'-type strata, and lies at the very base of the white massive Nummuliterich grainstones (facies 14b). Similarly, Microcodium-bearing calciturbidites characterize the late Paleocene calciturbidites in the Flysch Trough (facies 13).

Petrographical evidence from the MaastrichtianEocene Tamezzakht calciturbidites (facies 6-11) and from the Béni Ider Flysch Trough (facies 2, 7 and 13), show that the reworked lithoclasts were inherited from Triassic-early Jurassic, massive carbonate formations, mainly dolomites and white massive limestones, as well as from latest Jurassic-earliest Cretaceous pelagic series, namely Calpionella- and/or Saccocoma-rich mudstones. Complementary results have been obtained from equivalent late Cretaceous-early Oligocene calciturbidite strata of the Béni Ider area by Blumenthal et al. (1958), and recently by El Kadiri et al. (2003, 2006). Interestingly, such facies make up precisely the successions known in the Internal Dorsale units (e.g. Griffon 1966; Raoult 1966; Nold et al. 1981; El Kadiri et al. 1989; Maaté 1996) and the Jbel Moussa Group (El Kadiri et al. 1990). In contrast, lithoclasts derived from key facies of the External Dorsale (red radiolarites, Aptychusrich mudstones) are lacking despite the fact that the 


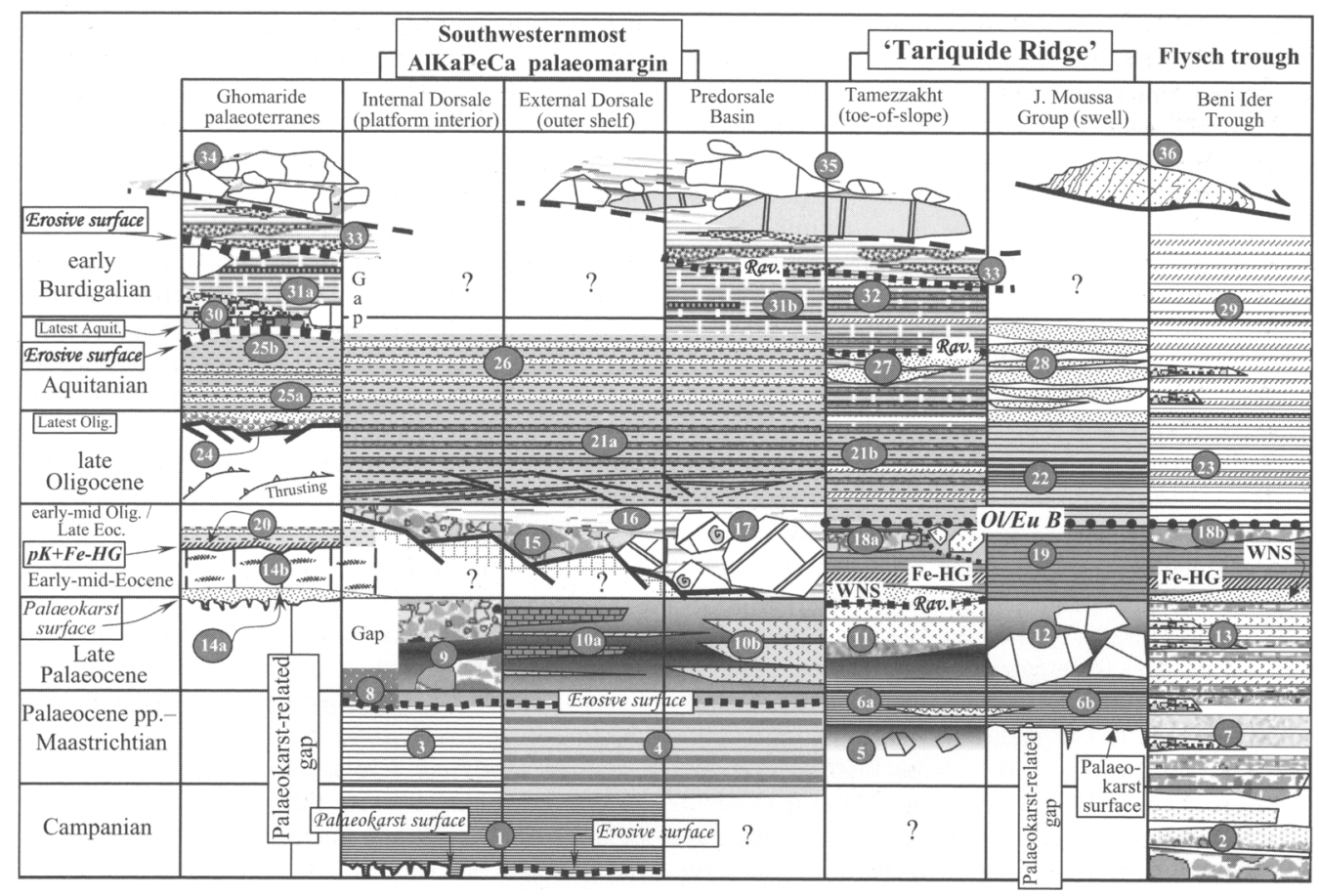

Fig. 4. Facies correlation and the tectonosedimentary events in the southwesternmost AlKaPeCa palaeomargin, the Tariquide Ridge and the Flysch Trough, based on selected data from: the Talembote area (Ghomaride terranes), Oued El Gharraq and Hafat Srir sections (Internal Dorsale), J. Lakraa, Hafat Nator, Saaden and Ametrasse-Bettara units (External Dorsale), Chrafate Klippes (Predorsalian domain), Beliounis and Ras Leona Klippes of the eastern part of the J. Moussa Group (Tariquide Ridge) and the Oued-El-Kébir successions (Béni Ider trough). 1, 'Capas Rojas'-type marlstones; 2, thick-bedded calciturbidites; 3, 'Capas Blancas'-type marlstones; 4, variegated marls (scaglia rossa facies); 5, black shales and resedimented blocks; 6 , ochre-red marlstones and slope calcarenites in Tamezzakht (6a) and the eastern J. Moussa Group (6b); 7, calciturbidite-black shale alternation; 8 , glaucony-rich bioclastic wackestones of the Oued El Gharraq section); 9, chaotic megabreccias and black shales (Kobat Sidi Kmim section); 10, black-shale pelagic limestone alternation (10a) and Microcodium-bearing turbidites and pelagic mudstone (10b); 11, Microcodium-rich, thick-bedded calciturbidites; 12 , hectometre-scale olistoliths, i.e. eastern elements of the J. Moussa Group; 13, medium- to thick-bedded Microcodium-rich calciturbidites (late Paleocene); 14a, early Eocene, Nummulite-bearing white sandstones; 14b, Nummulite-rich massive white limestones; 15, latest Eocene-earliest Oligocene coarse-grained conglomerates (the so-called Breccias Nummuliticas); 16, variegated marls; 17, large-scale olistoliths embedded within the latest Eocene-early Oligocene variegated marls (i.e. Chrafate Klippes, Assifane blocks, etc.); 18a, 18b, coarse-grained calciturbidites and olistoliths; 19, ochre-red lime-poor shales (RSF); 20, yellow soft marls with thin intercalations of sandstones (Bartonian); 21a, micaceous, wood-debris-bearing, carbonate sandstones, i.e. the so-called 'Grès Roux' (late Oligocene-(?)early Aquitanian); 21b, 'Grès Roux'-micaceous sandstones alternation and yellow soft pelagic marls (mid- to late Oligocene); 22 , green and yellow pelagic marls underlying the Beliounis sandstones; 23, thin-bedded micaceous sandstones and yellow marls; 24, holoquartzose puddingstones, with scarce granite pebbles (basal conglomerate of the Alozaina-type formation): latest Oligoceneearly Aquitanian; 25a, yellow sandstone-marl alternation; 25b, yellow soft pelagic marls (late Aquitanian pro paste); 26, fine-grained yellow sandstones (Aquitanian); 27, channelized Beliounis-type sandstones (late OligoceneAquitanian); 28, Aquitanian Beliounis sandstones (cropping out in the village of Beliounis); 29, thick-bedded micaceous sandstones; 30 , chaotic basal breccias and olistoliths containing a mixture of carbonate clasts as well as granite and basalt pebbles; 31, early Burdigalian Viñuela-type marlstones with thin chert levels, cropping out in the Talembote area (31a) and in the Predorsalian Chrafate Klippe zone (31b); 32, 'Grès Roux'-micaceous sandstones alternation and Viñuela-type marlstones (early Burdigalian); 33, tobacco brown pelites and Numidian-type sandstones (early to mid-Burdigalian) with resedimented blocks inherited from lost Ghomaride terranes; 34, chaotic complex reworking a mixture of blocks inherited from the Internal Dorsale and the Ghomaride cover; 35, chaotic complex reworking blocks from both the Internal and the External Dorsale; 36, nappe emplacement, probably triggered from late Burdigalian time. 
latter domain was palaeogeographically placed between the Internal Dorsale and the Tamezzakht area. Thus, calciturbidites of the Tamezzakht succession (and those of the Béni Ider succession) are likely to have been derived from an external shallow-water high area and not from the neighbouring Dorsale Calcaire. Support is given to this assumption by the following three criteria. (1) Both the Internal Dorsale and the external Dorsale during this time interval were completely drowned, as is clearly shown by the three ubiquitous pelagic facies: 'Capas Rojas' (Campanian), 'Capas Blancas' (Maastrichtian) and black shales (mainly of late Paleocene age). In contrast, the petrographical evidence shows the abundance of rust-coloured, palaeo-altered clasts in the Béni Ider and Tamezzakht Paleocene calciturbidites, which indicates that this clastic material was reworked from an adjacent emerged area. (2) The east-moving slump structures in the late Cretaceous-Paleocene calcarenites point to east-dipping (towards the internal zone) palaeoslopes. (3) The palaeocurrent directions indicate currents flowing towards the internal domain and directed $\mathrm{N} 70^{\circ} \mathrm{E}-\mathrm{N} 85^{\circ} \mathrm{E}$, mainly $\mathrm{N} 80^{\circ} \mathrm{E}$.

In contrast to the late Paleocene black shales and Microcodium-bearing pelagic black mudstones of the Dorsale Calcaire (facies 9 and 10a) the coeval thick-bedded black calciturbidites of the Predorsalian (facies 10b), Tamezzakht (facies 11) and Béni Ider series (facies 13) are almost exclusively made up of Microcodium crystal grains. The Microcodium colonies (originally defined by Glück 1912) are known to correspond to microbial mats 'decaying' limestones on palaeosoils (Freytet 1970; Bodergat 1974) and palaeokarst surfaces (Meyer 1987; El Kadiri et al. 1992). Thus, the latter Microcodium-rich calciturbidites were sourced from large-scale emerged karstic areas, which cannot be envisaged in the Dorsale Calcaire, as the latter was totally drowned during Campanian-Paleocene times (El Kadiri et al. 1989, 1992). It is noteworthy that the basinward export of the greatest volume of Microcodium material was mostly triggered during the late Paleocene transgressive regime (compare the. 'transgressive washing' process described by El Kadiri et al. 2006).

These important results are in accordance with the 'Tariquide Ridge' hypothesis of Durand-Delga (1972), which postulates that an isolated pelagic platform should be reconstructed in the northernmost part of the External zones (i.e. Jbel Moussa Group). The above-mentioned petrographical data strongly suggest that the 'Tariquide Ridge' would have had an important southward prolongation in the external zones and therefore would have separated the Predorsalian zone from the Mauretanian Flysch Trough during Jurassic-early Oligocene times. Thus, the Predorsalian zone significantly differs from the initial Predorsalian scheme of Didon et al. (1973) and Olivier (1984) who reconstructed the Predorsalian as a narrow transitory palaeogeographical zone directly connected to the external Flysch Trough. The scheme proposed here may explain why the Predorsalian zone did not receive the widespread early Cretaceous sandstone flysch (i.e. Tisirene flysch). Interestingly, the fact that the Predorsalian series received intercalations of Numidian-like sandstone flysch during latest Oligocene-Aquitanian times may indicate that an important tectonic event occurred during the mid- to late Oligocene and resulted in the disappearance of the so-called 'Tariquide Ridge'. We shall see below that this turning event: (1) was immediately preceded by large-scale resedimentation phenomena (latest Eocene-early Oligocene), partly reworking the material of the above-mentioned ridge itself; (2) was coeval with the onset of the widespread micaceous sandstone flysch (i.e. Béni Ider flysch), which indicates a tectonically raised new clastic source.

At present, late Cretaceous-Paleocene marine strata are unknown in the Ghomaride domain (Maaté 1984, 1996; El Kadiri 1991). In almost all the patched outcrops of the carbonate cover, discovered in this domain, white Nummulite-bearing carbonate sandstones (WNS, Fig. 3) of earliest Eocene (Illerdian) age (facies 14a, Fig. 4) directly fill the karstic cavities developed in the Liassic carbonate successions (e.g. El Onzar unit, El Kadiri et al. 1992). It is noteworthy that all the early Eocene transgressive shallow-water limestones at present known in the Ghomaride domain are never found directly discordant on the Palaeozoic schists. The fact that they are fundamentally linked to early Jurassic strata (e.g. El Onzar and Talembote sections, Fig. 3) and frequently occur as olistolithes within the Alozaina- and Viñuelatype Tertiary formations (e.g. Talembote section, Fig. 3), strongly suggests that these fragments of the assumed early Eocene 'Ghomaride cover' were originally derived from Ghomaride-like lost terranes and not from the at present defined Ghomaride units. A similar conclusion may be inferred from the basal conglomerates of these two Tertiary formations (El Kadiri et al. 2001; Hlila 2005) and from coeval conglomerates overtopping the Tertiary Ametrasse unit (southern external Dorsale, Nold et al. 1981; Hlila 2005), which are, in both cases, rich in granite, basalt pebbles and reefal blocks of unknown origin. The fact that these conglomerates preferentially occur close to the Ghomaride-Dorsale contact (e.g. Talembote, Béni Maaden) and within the Dorsale Calcaire itself, strongly suggests that their source was located between the Ghomaride terranes and the Dorsale Calcaire. 
Regarding the successive transgressive peaks shown in the long- and short-term eustatic curves by Haq et al. (1987) and Hardenbol et al. (1998, charts 1 and 2), the late Cretaceous-Paleocene transgressive peaks were markedly higher than those of Eocene times. This leads us to suggest that: (1) the Ghomaride realm (sensu lato) experienced a long-term Mesozoic karstic regime (El Kadiri et al. 1992); (2) the onset of the Tertiary marine regime from the beginning of the Eocene was driven by a regional-scale tectonic collapse. Interestingly, equivalent transgressive Nummulitebearing sandstones that developed in a strikingly identical lithofacies make up a metre-scale interval at the base of the Eocene calciturbidites in many sections throughout the Béni Ider area (Fig. 3). They can serve as key strata not only because of their high correlation potential, but also as they allow the onset of a transgressive regime to be delineated even within near-homogenous base-of-slope calciturbidite packages. In the Oued-El-Kébir section (Fig. 3) a conspicuous Thallassinoidesburrowed firmground surface (i.e. Glossifungitestype surface; e.g. Savrda 1995; MacEachern \& Burton 2000; Savrda et al. 2001a,b) immediately follows the WNS facies, and probably marks the related transgressive peak.

Importantly, the same light-coloured carbonate sandstones exist in the Tamezzakht section. They clearly erode the lime-free siliceous green shales of the underlying facies (facies 11), upon which they unconformably rest along a low-angle hidden discontinuity (in the sense of Clari et al. 1995). Two Fe-encrusted surfaces cap the immediately overlying beds and may be regarded, in the same way, as corresponding to the consequent transgressive peak. Hence, the following thin-calciturbiditeintercalated ochre-red shales could normally correspond to the late highstand-lowstand regime, during which terrigenous-mud-dominated packages are the most common components (e.g. Savrda et al. 2001a).

Within the Tamezzakht succession, conspicuous grain-flow events occur in the upper part of the ochre-red shales of Eocene-early Oligocene age (facies 18a), probably close to the EoceneOligocene boundary. They laterally evolve into a discontinuous olistostrome-like formation, which can rest uncomfortably on the underlying strata of late Cretaceous-Paleocene age (facies 5 and 6). This collapse event may correlate with the regional-scale onset of chaotic breccias in both the Dorsale Calcaire (facies 15, Breccias Nummuliticas, Nold et al. 1981) and the Flysch Trough. In the former (e.g. Hafat Srir section, Fig. 3) they unconformably rest on the Triassic-Liassic massive carbonate formations and seal large-scale extensional structures (see also the geological maps of Kornprobst et al. 1975,
1979). In the second, chaotic breccias cap the Eocene calciturbidites before being buried under an ochre-red shale-dominated succession (facies 18b). In addition, El Kadiri (1984), De Wever et al. (1985) and Ben Yaïch et al. (1988) showed that the sedimentary Chrafate Klippes (facies 17), which represent the southernmost part of the Predorsalian domain, were embedded within variegated marls of latest Eocene-early Oligocene age (facies 16). Concurrently, the absence of coeval marine strata in the Ghomaride domain is noteworthy. Marine sedimentation seems not have returned before the onset of the widespread latest Oligocene transgressive holoquartzose puddingstones (facies 24), which lie at the base of the Aquitanian yellow marl-sandstone alternation (facies 25, i.e. Ciudad-Granada-Fnideq Formation).

In the northernmost part of the Ghomaride domain, the Fnideq sandstones commonly seal normal faults at different scales, which points to a regional extensional event. In the Dorsale-Predorsalian couplet, the rustcoloured sandstones (facies 21a) that start shortly before, during the late Oligocene, also seal normal faults at different scales. A more comprehensive assessment of the regional-scale tectonic controls that might be proposed for the whole late Oligocene history needs to account for other time-equivalent events known throughout the whole Betic-Rif Internal zones, which is beyond the scope of this paper. It should be noted, for instance, that this extensional event in both the Ghomarides and Dorsale Calcaire occurred just after the mid- to late Oligocene paroxysmal phase that is well documented in the Ghomaride units (e.g. Chalouan 1986; DurandDelga et al. 1993).

The abrupt facies change that is well delineated in the field between the 'oligotrophic' ochre-red shales (facies 19 in the Tamezzakht, J. Moussa and Béni Ider areas) and the 'eutrophic' green pelagic marls (oligotrophy-eutrophy boundary, $\mathrm{Ol} / \mathrm{Eu} \mathrm{B}$, Fig. 4) is seemingly linked to the welldocumented global-scale climatic change that occurred close to the Eocene-Oligocene boundary. It is evidenced by the turnover of planktonic Foraminifera (see examples by Molina et al. 1986, 1988, 1996, amongst others) as a result of a sudden global cooling event paired with enhanced ocean circulation (e.g. Pomerol 1985; Marty et al. 1988; Zachos et al. 1993, 1995; Diester-Haass \& Zahn 1996; Barnes 1999). These climatic events were essentially induced by the immediately preceding tectonic collapses, which resulted in the opening and/or rearrangement of intercontinental seaways (e.g. between Antarctica and South America, Pomerol 1985; Wilson et al. 1998). Thus, the successions selected in this study provide an interesting record of such a twofold tectonic and climatic event: the coarse-grained 
conglomerates (facies 15, 17 and 18) and olistostromes (facies 17) fit well with this scenario.

We would like to compare this Oligocene scenario with two strikingly near-identical events, which occurred close to the Jurassic-Cretaceous boundary and at the Turonian-early Senonian boundary, respectively. The former was recorded similarly by an abrupt facies change between the 'oligotrophic' ochre-red radiolaritic shales (late Jurassic) and the coccolith-formed yellow hemipelagic marls (late Tithonian-early Cretaceous). This is the Kuenen event (Roth 1989), which is known throughout the Tethyan realm to be similarly induced by a tectonic-mediated ocean-circulation intensification (De Wever et al. 1986; El Kadiri $2002 b$ ). In the latter case the early Senonian eutrophic green pelites sharply seal normal faults affecting the immediately underlying ochre-red Turonian shales and calciturbidites (El Kadiri et al. 2003). These examples support the causal link proposed above between tectonics and abrupt facies change. In the case of the onset of the early to mid-Oligocene eutrophic shales (Dorsale calcaire; Tamezzakht, Béni Ider), the related tectonic event may obviously be linked to the Ghomaride paroxysmal phase.

The rust-coloured sandstones (the so-called 'Grès Roux'; Fallot 1937; Griffon 1966) typify the late Oligocene siliclastic regime in all the stratigraphic series known in the Dorsale Calcaire (facies 21a) and last until the early Burdigalian in the Tamezzakht succession (facies $21 \mathrm{~b}$ and 32 ). Petrographical evidence shows that this regime reworks a mixture of metamorphic-rock-derived, immature lithoclasts that do not seem to be sourced from the Rifian Sebtide-Ghomaride terranes or from their Betic counterparts. Their petrographical features seem to us similar to those described by Puglisi et al. (2001) in both the Tertiary Ghomaride cover and the time-equivalent strata in the Béni Ider flysch successions. About 10 palaeocurrent directions measured on the sole of the sandstone beds indicate currents directed $\mathrm{N} 20^{\circ}-\mathrm{N} 60^{\circ}$, mainly $\mathrm{N} 30^{\circ}-\mathrm{N} 40^{\circ}$, and flowing from the $\mathrm{SW}$ to the $\mathrm{NE}$ (i.e. towards the internal domain from an external source). Thus, like the underlying calciturbidites, these sandstone flows could be sourced from (an) external lost terrane(s). Seemingly, the same may be true for the Dorsale-Calcaire 'Grès Roux', the sole of which gives evidence of north-flowing currents (our measurements were taken in the Tamezzakht area, i.e. in the Hafat Srir section along the road to the television mast). In the latter domain the current directions were probably modified by a near north-south-directed half-graben physiography. However, reconstruction of the late Oligocene-Aquitanian sandstone source(s) remains a hard task and requires more dating controls and careful regional-scale correlations (partly involving sedimentological and environmental data as a comparison tool) throughout both the Internal and External zones. For instance, it is noteworthy that: (1) a tectonic event (i.e. the mid- to late Oligocene paroxysmal phase in the Ghomaride domain) could be responsible for the emplacement (and/or emergence) of new supplying terranes close to or partly on the previous nummulitic carbonate source, which resulted in its complete and irreversible drowning under the siliciclastic accumulations; (2) the whole palaeogeographical setting was likely to undergo significant modifications (i.e. in placing together previously distant areas). Concurrently with the rust-coloured sandstones, this result may additionally be supported by the interlayered metre-scale micaceous sandstones, which undoubtedly reflect the rise of another juxtaposed terrigenous source.

In the Ghomaride domain, the chaotic, coarsegrained conglomerate lying at the very base of the early Burdigalian marlstones (i.e. Viñuela Formation) is well documented in the Betic Internal zones as transgressively onlapping the Palaeozoic terranes (Sanz de Galdeano et al. 1993; Serrano et al. 1995; López-Garrido \& Sanz de Galdeano 1999). These rocks erode the Aquitanian yellow pelagic marls of the underlying formation (Alozaina Formation) and could indicate a tectonically controlled collapse. This large-scale event resulted in the generalization of the siliceous marlstones of hemipelagic signature throughout the Betic-Rif Internal zones. The fact that this facies of high correlation potential makes up decametre-thick intervals in the upper third of the Tamezzakht succession (facies 32) and the Predorsalian units (facies 31b) leads us to the conclusion that the palaeogeographical setting of the latter external units became relatively close to the structuring of the Internal zones during the late Aquitanianearly Burdigalian.

With regard to the pelagic sedimentation regime, it seems possible that there are three lines of comparison between the Tamezzakht succession and that of the Talembote area recently described by El Kadiri et al. (2001) close to the Internide-Externide front (Fig. 3). (1) In the Tamezzakht area, the entire midOligocene-early Burdigalian pelagic marly deposition develops in a rhythmic alternation of centimetre to decimetre intervals of yellow marls and 'early' Viñuela-type green marlstones, with the latter cyclic component being dominant in early Burdigalian time. In the Talembote area, these two facies are clearly separated in time as two contrasted lithological intervals, with an erosional discontinuity between them close to the Aquitanian-Burdigalian transition (see Fig. 3). Thus, the difference between the Tamezzakht pelagic deposition (i.e. close to the 
External Domain) and the Talembote one (Internal Domain) may basically be related to the diachronism of the Viñuela-type marlstones. (2) Lithofacies and biostratigraphic dating allow us to distinguish in the Predorsalian domain two types of early Miocene holoquartzose sandstones: the first corresponds to the classical Numidian-like, yellow to rust-coloured sandstones (facies 27 and 28, Fig. 4) defined by Durand-Delga (1972) and Didon et al. (1973) in the village of Beliounis (J. Moussa Group) as characterizing the depositional regime of the Predorsalian zone during the late Oligocene-Aquitanian, (i.e. synchronously with the external Numidian flysch deposition). This facies, sometimes poorly consolidated, is generally poorly graded and all the quartz grains are rounded and may be white, red or black. Very similar yellow sandstones coevally spread over the Ghomaride-Malaguide domains (Fnideq and Alozaina Formations, respectively, facies 25a, Fig. 4). We have found identical facies within the late Oligocene-Aquitanian levels of the Tamezzakht succession, a result that lends additional support to ascribing the Tamezzakht area to the Predorsalian zone. The second type of sandstone facies corresponds to tobacco brown holoquartzose sandstones, in which the quartz grains may be rounded or not and are predominantly glass-green coloured. Individual beds may show graded bedding into fine pelites. This second sandstone facies strictly occurs within the tobacco brown pelites of early to mid-Burdigalianage (El Hatimi 1982; El Kadiri et al. 2001; Hlila 2005) and its distinction fits well with the early 'Neonumidian'-sandstone concept defined by Bourgois (1978) in the Internal zones of the Betic Cordilleras.

The upper levels of early Burdigalian tobacco brown pelites receive increasing gravity-flow discharges that evolve into huge olistostrome complexes carrying large olistoliths. These derived from either the Ghomaride-Internal Dorsale couplet (facies 34, example in the Talembote area) or the External Dorsale (facies 35; for the examples occur in Tamezzakht, Chrafate Klippes and Kobat El Kesskasse olistostrome) with Palaeogene variegated marly strata being trapped between them. The immediately superimposed Dorsale nappe pile may tentatively be considered as resulting from the culmination of the same phenomenon.

\section{Conclusion}

The aim of this paper was to provide a basis for synthesizing the more significant facies, discontinuities and gravity-flow discharges from the Rif Internal Domain and its surroundings. It seems that almost all the data point to tectonic events of regional or global scale. The above interpretation provides the three following results.

(1) Apart from certain widespread facies of high correlation potential, the late Cretaceous-early Oligocene strata studied above exhibit important differences, so that their respective depocentres should be located in distant palaeogeographical areas. We can retain the possibility that: (a) important Ghomaride-like lost terranes could be located between the present-day defined Ghomaride units and the Internal Dorsale; (b) symmetrically, one or several isolated carbonate platforms could be located within the external zones, i.e. 'Tariquide'like ridge(s), which have played a major role as the source delivering, at a large scale, calciturbidites to the Predorsalian and Flysch basins.

(2) The relationship between the internal and the external zone, which has long been considered as being marked by a narrow transitional zone (the classical Predorsale concept), was likely to have involved more than a simple palaeogeographical area, as shown by the Chrafate klippes and the J. Moussa Group, which are remains of a wider and more complex area. The latter probably underwent successive palaeogeographical modifications with time. For instance, it should be noted that during late Cretaceous-Eocene times, the Predorsalian zone(s) were separated from the Flysch Trough by the above-mentioned 'Tariquide'-like ridge(s). The collapse and final disappearance of the latter occurred during the latest Eocene-early Oligocene, i.e. concurrently with (a) the disappearance of the external prolongation of the external Dorsale units (i.e. Chrafate Klippe olistostromes), (b) the onset of the Dorsale calcaire megabreccias (Breccias Nummuliticas) and (c) other large-scale gravity events (e.g. Talembote olistostromes).

(3) The major discontinuities, coarse-grained discharges and facies changes (e.g. newly raised sources) may be ascribed to distal reverberations of the contractional phases that occurred in the old Ghomaride realm during the early to mid-Oligocene-early Burdigalian time interval. The progressive homogenization of some key facies (rust-coloured sandstones, Beliounis and Neo-Numidian ones as well as the Viñuela-type marlstones) to previously distant palaeogeographical zones during Aquitanian-early Burdigalian times may be paralleled by the shortening processes that resulted in a new palaeogeographical setting.

However, reconstructing a reliable tectonosedimentary evolution requires new insights into the following issues.

(1) What was the triggering mechanism(s) of the chaotic, coarse-grained gravity flows? Despite these commonly occuring as deposits that transgressively 
overlie previous emerged areas, their intercalation within and/or at the top of pelagic marly successions leads us to raise the question of contractional (nappe front) versus extensional (normal fault) tectonic controls. A eustatic signature cannot be excluded, as megabreccias are generally ascribed to lowstand phases (e.g. Haas 1999; Ineson \& Surlyk 2000).

(2) What is the significance of the four Palaeogene-early Miocene formations (with discontinuities between them), well documented in the Malaguide-Ghomaride domain, in terms of eustatic controls (i.e. Exxon sequence) versus a tectonic one?

(3) What is the extent of the entirely disappeared palaeogeographical zones? Indeed, the clastic mixture reworked in the Alozaina and Viñuela formations (Betic Cordillera) and in their Rif counterparts, points to very extensive lost source areas. This leads us to question how far we can still maintain the classical scheme that immediately juxtaposes the Sebtides, Ghomarides, Dorsale, Predorsale and Mauretanian flysch?

(4) Was the kinematics of nappe emplacement determined by tectonic driving forces (subduction phases, Lonergan \& White 1997; Chalouan et al. 2001) or by gravitational ones (Weijermars 1987; Doblas \& Oyarzun 1989; El Kadiri et al. 1995)? A possible continuum process and/or causal link between them may tentatively be suggested in the case of the large-scale gravity flows proved to immediately precede the nappe-pile emplacement.

Integrated approaches involving sedimentology, sequence-stratigraphic interpretation, comprehensive inventory of sedimentary discontinuities, close biostratigraphic dating and detailed mapping, as well as more extended regional correlations, are expected to shed additional light on these issues, and are in progress.

The authors express their sincere thanks to A. Michard (University of Paris) and W. Wildi (University of Zürich) for their thorough reviews and constructive remarks. This work was financially supported by both the Société Nationale d'Etude du Détroit, SNED, Rabat, Morocco and the 'Junta de Andalucia' Project A49/02 (M): 'Las Formaciones cenozicas de la zona Interna...' (Spain).

\section{References}

ANDRIEUX, J. 1971. La structure du Rif central. Etude des relations entre la tectonique de compression et les nappes de glissement dans un tronçon de la chaîne alpine. Notes et Mémoires du Service Géologique du Maroc, 235, 1-155.

AZAÑon, J. M. \& CRESPo-BlanC, A. 2000. Exhumation during a continental collision inferred from the tectonometamorphic evolution of the Alpujarride Complex in the central Betics (Alboran domain, SE Spain). Tectonics, 19, 549-565.
Azanon, J. M., Garcia-Duenas, V. \& GoffÉ, B. 1998. Exhumation of high-pressure metapelites and coeval crustal extension in the Alpujarride complex (Betic Cordillera). Tectonophysics, 285, $231-252$.

Balanya, J. C. \& Garcia-Duenas, V. 1987. Les directions structurales dans le domaine d'Alboran de part et d'autre du Détroit de Gibraltar. Comptes Rendus de l'Académie des Sciences, Série II, 304(15), 929-932.

BARNES, C. R. 1999. Palaeoceanography and palaeoclimatology: an Earth system perspective. Chemical Geology, 161, 17-35.

BEN YAÏCH, A. 1991. Evolution tectono-sédimentaire $d u$ Rif externe centre occidental (régions de M'Sila et Ouezzane, Maroc). Doctorat d'Etat Thesis, University of Pau, France.

Ben Yaïch, A., Maaté, A., Feinberg, H., Magné, J. \& Durand-Delga, M. 1986. Implications de niveaux du Miocène inférieur dans les retrochevauchements de la Dorsale calcaire rifaine (Maroc): signification à l'échelle de l'Arc de Gibraltar. Comptes Rendus de l'Académie des Sciences, Série II, 302(8), 587-592.

Ben Yaïch, A., Duée, G., El Hatimi, N. \& EL KADIRI, KH. 1988. La formation à klippes sédimentaires d'âge oligo-burdigalien du Rif septentrional (Maroc): signification géodynamique. Notes et Mémoires du Service Géologique du Maroc, 334, 99-126.

BenZAGgAGH, M. 1996. Le Malm supérieur et le Berriasien dans le Prérif interne et le Mésorif (Rif, Maroc): stratigraphie, sédimentologie, paléogéographie et évolution tectono-sédimentaire. Doctorat d'Etat Thesis, University of Rabat.

Blumenthal, M., Durand Delga, M. \& Fallot, P. 1958. Données nouvelles sur le Tithonique, le Crétacé et l'Eocène de la zone marno-schisteuse du Rif septentrional (Maroc). Notes et Mémoires du Service Géologique du Maroc, 16(143), 35-58.

Bodergat, A. M. 1974. Les Microcodium, milieux et modes de développement. Documents du Laboratoire de Géologie de la Faculté des Sciences de Lyon, 62, 137-235.

Boulllin, J. P., Durand-Delga, M., Gélard, J. P., ET AL. 1970. Définition d'un flysch Massylien et d'un flysch Maurétanien au sein des flyschs allochtones de l'Algérie. Comptes Rendus de l'Académie des Sciences, 270, 2249-2252.

Bouillin, J. P., Durand-Delga, M. \& Olivier, Ph. 1986. Betic-Rifian and Tyrrhenian arcs: distinctive features, genesis and development stages. In: Wetzel, F.-C. (ed.), The Origin of the Arcs. Elsevier, Amsterdam, 281-304.

Bourgols, J. 1978. La transversale de Ronda. Cordillères Bétiques, Espagne. Données géologiques pour un modèle d'évolution de l'arc de Gibraltar. Doctorat d'Etat Thesis, University of Besançon.

Bouybaouène, M. L., Goffé, B. \& Michard, A. 1995. High-pressure, low-temperature metamorphism in the Sebtides nappes, northern Rif, Morocco. Geogaceta, 17, 117-119.

Burkhalter, R. M. 1995. Ooidal ironstones and ferruginous microbialites: origin and relation to 
sequence stratigraphy (Aalenian and Bajocian, Swiss Jura Mountains). Sedimentology, 42, 57-74.

Calvert, A., Sandvol, E., Seber, D., et al. 2000. Geodynamic evolution of the lithosphere and upper mantle beneath the Alboran region of the western Mediterranean: constraints from travel time tomography. Journal of Geophysical Research, 105, $10871-10898$.

Chalouan, A. 1986. Les nappes Ghomarides (Rif septentrional, Maroc), un terrain varisque dans la chaîne Alpine. Doctorat d'Etat Thesis, University Louis Pasteur, Strasbourg.

Chalouan, A. \& Michard, A. 1990. The Ghomaride nappes, Rif, coastal Range, Morocco: a Variscan chip in the Alpine belt. Tectonics, 15, 187-200.

Chalouan, A., Saji, R., Michard, A. \& Bally, A. W. 1997. Neogene tectonic evolution of the south-western Alboran basin as inferred from seismic data of Morocco. AAPG Bulletin, $\mathbf{8 1}$ $1161-1184$.

Chalouan, A., Michard, A., Feinberg, H., Montigny, R. \& SADDIQI, O. 2001. The Rif mountains building (Morocco): a new tectonic scenario. Bulletin de la Société Géologique de France, 172(5), 603-616.

Chalouan, A., El Mrihi, A., El Kadiri, Kh., Bahmad, A., SALHi, F. \& Hlila, R. 2006. Mauretanian flysch nappe in the northwestern Rif Cordillera (Morocco): deformation chronology and evidence for a complex nappe emplacement. In: Moratti, G. \& Chalouan, A. (eds) Tectonics of the Western Mediterranean and North Africa, Geological Society, London, Special Publications, 262, $161-175$.

Clari, P. A., Dela Pierre, F. \& Martire, L. 1995. Discontinuities in carbonate successions: identification, interpretation and classification of some Italian examples. Sedimentary Geology, 100, 97-121.

Comas, M. C., Garcia-Dueñas, V. \& Jurado, V. 1992. Neogene tectonic evolution of the Alboran Sea from MCS data. Geomarine Letters, 12(2-3), 157-164.

De Wever, P., DuéE, G. \& El Kadiri, Kh. 1985. Les séries stratigraphiques des klippes de Chrafate (Rif septentrional, Maroc): témoins d'une marge continentale subsidente au cours du Jurassique-Crétacé. Bulletin de la Société Géologique de France, 8th series, I(3), 363-379.

De Wever, P., Ricou, L. E. \& Fourcade, E. 1986. La fin brutale de l'optimum radiolaritique au Jurassique terminal: l'effet de la circulation océanique. Comptes Rendus de l'Académie des Sciences, Série II, 302(9), 665-670.

Didon, J. 2006. Carte géologique du Rif, feuille de Khémis Béni-Arouss, 1/50 000. Notes et Mémoires du Service Géologique du Maroc.

Didon, J., Durand-Delga, M. \& Kornprobst, J. 1973. Homologies géologiques entre les deux rives du détroit de Gibraltar. Bulletin de la Société Géologique de France, 15, 77-105.

DiESTER-HAASS, L. \& ZAHN, R. 1996. EoceneOligocene transition in the Southern Ocean: history of water mass circulation and biological productivity. Geology, 24, 163-166.

Doblas, M. \& Oyarzun, R. 1989. Neogene extensional collapse in the Mediterranean (Betic-Rif Alpine orogenic belt): implications for the genesis of the Gibraltar Arc and magmatic activity. Geology, 17, 430-433.

Durand-Delga, M. 1972. La courbure de Gibraltar, extrémité occidentale des chaînes alpines, unit l'Europe et l'Afrique. Eclogae Geologicae Helveticae, 65, 267-278.

Durand-Delga, M. 1980. La Méditerranée occidentale: étapes de sa genèse et problèmes structuraux liés à celle-ci. Livre Jubiliaire de la Société Géologique de France à la Mémoire de P. Lucas. Mémoire hors série, 10, 1830-1980.

Durand-Delga, M. \& Didon, J. 1984a. Carte géologique du Rif, Feuille de Ksar Es-Srhir, 1/50000. Notes et Mémoires du Service Géologique du Maroc, 295.

Durand-Delga, M. \& Didon, J. 1984b. Carte géologique du Rif, Feuille de Melloussa, 1/50000. Notes et Mémoires du Service Géologique du Maroc, 296.

Durand-Delga, M. \& Villiaumey, M. 1963. Sur la stratigraphie et la tectonique du Jebel Moussa. Bulletin de la Société Géologique de France, 7th series, 5(1), 70-79.

Durand-Delga, M., Hottinger, L., MarÇais, J., Mattauer, M., Milliard, Y. \& Suter, G. 1962. Données actuelles sur la structure du Rif. Livre à la Mémoire de Paul Fallot, Société Géologique de France. Mémoire hors série, 1, 399-422.

Durand-Delga, M., Feinberg, H., Magné, J., Olivier, PH. \& Anglada, R. 1993. Les formations oligo-miocènes discordantes sur les Malaguides et les Alpujarrides et leurs implications dans l'évolution géodynamique des cordillères Bétiques (Espagne) et de la Méditerranée d'Alboran. Comptes Rendus de l'Académie des Sciences, Série II, 317, 679-687.

EICHER, D. L. \& Diner, R. 1991. Environmental factors controlling Cretaceous limestonemarlstone rhythms. In: EinsEle, G., RiCKEN, W. \& SeILAKher, A. (eds) Cycles and Events in Stratigraphy, Springer, Berlin, 79-93.

Einsele, G. \& RicKen, W. 1991. Limestone-marl alternations-an overview. In: EINSELE, G., Diplôme d'Etudes Ricken, W. \& SeILACHER, A. (eds) Cycles and Events in Stratigraphy. Springer, Berlin, 23-47.

El Hatimi, N. 1982. Contribution à l'étude géologique et structurale de la région d'Assifane (Rif, Maroc). Diplôme d'Etudes Thesis, University of Rabat.

El Hatimi, N. 1991. Rifting mésozö̈que sur la bordure occidentale du Rif interne (Maroc). Evolution géodynamique d'un secteur de la marge ouest-téthysienne. Exemples du Haouz et du Groupe du J. Moussa. Doctorat d'Etat Thesis, University of Pau.

El Hatimi, N., Ben Yaich, A. \& El Kadiri, Kh. 1988. Evolution méso-cénozoïque à la limite Zones Internes-Zones Externes dans la chaîne 
rifaine. Bulletin de l'Institut Scientifique de Rabat, 12, 9-18.

EL KADIRI, KH. 1984. Les radiolarites jurassiques des klippes de Chrafate (Rif septentrional, Maroc): stratigraphie, taxonomie. Doctorat du zème cycle Thèse, University of Pau.

EL KADIRI, KH. 1991. La Dorsale Calcaire (Rifinterne, Maroc): Stratigraphie, sédimentologie et évolution géodynamique d'une marge alpine durant le Mésozoüque. Mise en évidence d'un modèle. Doctorat d'Etat Thesis, University of Tetuan.

EL KADIRI, KH. 2002a. Jurassic ferruginous hardgrounds of the 'Dorsale Calcaire' and the Jbel Moussa Group (internal Rif, Morocco): stratigraphical context and palaeoceanographic consequences of mineralization processes. Geologica Romana, 36, 33-70.

EL KADIRI, KH. 2002b. 'Tectono-eustatic sequences' of the Jurassic successions from the Dorsale Calcaire (internal Rif, Morocco): evidence from a eustatic and tectonic scenario. Geologica Romana, 36, 71-104.

El Kadiri, KH., Linares, A. \& Oloriz, F. 1989. La Dorsale calcaire interne entre les Accidents de l'Oued Martil et de l'Oued Laou (Rif septentrional, Maroc): évolutions stratigraphique et géodynamique au cours du Jurassique-Crétacé. Communicações Serviçios Geológicos de Portugal, 75, 39-65.

El Kadiri, Kh., Linares, A. \& Oloriz, F. 1990. Les éléments du Groupe du Jbel Moussa (Chaîne Calcaire, Rif, Maroc): évolutions stratigraphique et géodynamique au cours du Jurassique-Crétacé Communicações Serviçios Geológicos de Portugal, 76, $141-161$.

El Kadiri, KH., Linares, A. \& Oloriz, F. 1992. La Dorsale Calcaire rifaine (Maroc septentrional): évolution stratigraphique et géodynamique durant le Jurassique-Crétacé. Notes et Mémoires du Service Géologique du Maroc, 336, 217-265.

El Kadiri, Kh., Oloriz, F. \& Linares, A. 1995. Evolution tectono-sédimentaire alpine autour de l'Arc de Gibraltar et mise en évidence de la cinématique de remontée d'un dôme de l'asténosphère depuis le Jurassique jusqu'au Néogène. Geogaceta, 17, 104-106.

El Kadiri, Kh., Chalouan, A., El Mrihi, A., Hlila, R., Lopez-Garrido, A. C., SAnz de Galdeano, C. \& Serrano, F. 2000. Descubrimiento del Burdigaliense (Formación Viñuela) en la cobertera ghomáride de Ceuta (Rif Septentrional). Geogaceta, 28, 43-46.

El. Kadiri, K., Chalouan, A., El Mrihi, A., et $4 l$. 2001. Les formations sédimentaires olistolitiques de l'Oligocène supérieur-Miocène inférieur dans l'unité ghomaride des Béni Hozmar (secteur de Talembote, Rif septentrional, Maroc). Eclogae Geologicae Helveticae, 94, 313-320.

El. Kadiri, Kh., El Kadiri, K. \& Rahouti, A. 2003. Sédimentologie et ichnologie des calciturbidites du Crétacé supérieur-Oligocène inférieur de la série Maurétanienne (nappe des Béni Ider, Rif septentrional, Maroc): implications paléogéographiques. $\mathrm{Bul}$ letin de l'Institut Scientifique de Rabat, 25, 73-91.

El Kadiri, Kh., Serrano, F., Hlila, R., et al. 2005. Lithostratigraphy and sedimentology of the latest
Cretaceous-searly Burdigalian Tamezzakht Succession (Northern Rif, Morocco): consequences for its sequence stratigraphic interpretation. Facies, 50, 477-503.

El. Kadiri, Kh., Chalouan, A., Bahmad, A., Salhi, F. \& LiEMLAHI, H. (2006). 'Transgressive washing' concept: a sequence stratigraphic approach for calci- and siliciclastic turbidites. In: Moratti, G. \& Chalouan, A. (eds) Tectonics of the Western Mediterranean and North Africa. Geological Society, London, Special Publications, 262, 45-53.

FALlot, P. 1937. Essai sur la géologie du Rif septentrional. Notes et Mémoires du Service Géologique du Maroc, 4, 1-553.

FARINACCI, A. 1996. Depositional discontinuity and biosequence concept. Examples from Mesozoic western Tethys. Palaeopelagos, 6, 211-227.

FARINACCI, A. 2002. Palaeosol in Apennine carbonate platform connected with Jurassic 'Main Gap' discontinuity. Vallepiert Palaeosol. Geologica Romana, 36, 163-167.

FarinaCcI, A., Bölükbai, S. \& Ridolfi, V. 1997. The Tethyan Jurassic 'main gap' in the Tinaz Tepe section of the Barla Dag area, Western Taurus, Turkey. Palaeopelagos, 7, 7-26.

FeinberG, H. \& Olivier, Ph. 1983. Datation des termes aquitaniens et burdigaliens dans la zone prédorsalienne bético-rifaine et ses conséquences. Comptes Rendus de l'Académie des Sciences, Série II, 296, 473-476.

Feinberg, H., Maaté, A., Bouhdadi, S., DurandDelga, M., MaAte, M., Magné, J. \& Olivier, PH. 1990. Signification des dépôts de l'Oligocène supérieur-Miocène inférieur du Rif interne (Maroc), dans l'évolution géodynamique de l'Arc de Gibraltar. Comptes Rendus de l'Académie des Sciences, Série II, 310, 1487-1495.

FREYTET, P. 1970. Les dépôts continentaux et marins du Crétacé supérieur et des couches de passage à l'Eocène en Languedoc. Doctorat d'Etat Thesis, Université Orsay-Paris-Sud.

Frizon de LAmotTE, D. 1985. La structure du Rif oriental (Maroc). Rôle de la tectonique longitudinale et importance des fluides. Doctorat d'Etat Thesis, University Pierre et Marie Curie, Paris.

Fürsich, F. T., OsChmann, W., JAITLY, A. K. \& Singh, I. B. 1991. Faunal response to transgressiveregressive cycles: example from the Jurassic of western India. Palaeogeography, Palaeoclimatology, Palaeoecology, 85, 149-159.

Garcia-Dueñas, V., Balanya, J. C. \& Martinez MARTinez, J. M. 1992. Miocene extensional detachments in the outcropping basement of the northern Alboran basin (Betics) and their implications. Geo-Marine Letters, 12(2-3), 88-95.

GLück, H. 1912. Eine neue gesteinbildende Siphonee (Codiacée) aus dem marinen Tertiar von Suddeutschland. Mitteilungen der Badische Geologischen Landesanstalt, 7, 3-24.

Griffon, J. C. 1966. La Dorsale calcaire au sud de Tétouan. Notes et Mémoires du Service Géologique du Maroc, 184, 149-223.

Guerrera, J., Martin-Algarra, A. \& Perrone, V. 1993. Late Oligocene-Miocene syn-/late- 
orogenic successions in western and central Mediterranean chains from the Betic Cordillera to the southern Apennines. Terra Nova, 5, 525544.

HAAS, J. 1999. Genesis of late Cretaceous toe-of-slope breccias in the Bakony Mts, Hungary. Sedimentary Geology, 128, 51-66.

HaQ, B. U., Hardenbol, J. \& Vail, P. R. 1987. Chronology of fluctuating sea-levels since the Triassic. Science, 235, 1156-1167.

Hardenbol, J., Thierry, J., Farley, M. B., Jacquin, T., DE GRaciansky, P. C. \& VAIL, P. R. 1998. Mesozoic and Cenozoic sequence chronostratigraphic framework of European Basins. In: DE GRACIANSKY, P. C., HARDENBOL, J. JACQUiN, T. \& VAIL, P. R. (eds) Mesozoic and Cenozoic Sequence Stratigraphy of European basins. Society of Economic, Paleontologists and Mineralogists, Society for Sedimentary Geology, Special Publications, 60, 3-13.

HlilA, R. 1994. Etude des déformations miocènes dans la chaîne calcaire du Haouz, (entre Tétouan et le col du Drauy). Diplôme d'Etudes Supérieures Thesis, University of Tetuan.

HLILA, R. 2005. Evolution tectono-sédimentaire tertiaire au front ouest du domaine d'Alboran (Ghomarides et Dorsale calcaire, Rif septentrional, Maroc). Doctorat d'Etat Thesis, University of Tetuan.

InESON, J. R. \& Surlyk, F. 2000. Carbonate megabreccias in a sequence stratigraphic context; evidence from the Cambrian of Greenland. In: HunT, D. \& GAwTHORPE, R. L. (eds). Sedimentary Responses to Forced Regressions. Geological Society, London, Special Publications, 172, $47-68$.

Kornprobst, J. 1974. Contribution à l'étude pétrographique et structurale de la zone interne du Rif (Maroc septentrional). Notes et Mémoires du Service Géologique du Maroc, 251, 1-260.

Kornprobst, J. \& Durand-Delga, M. 1985. Carte géologique du Rif, Feuille Sebta, 1:50 000. Notes et Mémoires Service géologique du Maroc, 291.

Kornprobst, J., Wildi, W., Nold, M., Gutnic, M. \& Lespinasse, P. 1975. Carte Géologique du Rif, feuille de Bab Taza, 1/50.000. Notes et Mémoires du Service Géologique du Maroc, 288.

Kornprobst, J., Nold, M. \& WiLdi, W. 1979. Carte Géologique du Rif, feuille de Talembote, 1/50.000. Notes et Mémoires du Service Géologique du Maroc, 290.

LESPINASSE, P. 1975. Géologie des zone externes et des flyschs entre Chaouen et Zoumi (Centre de la chaîne rifaine du Maroc. Doctorat d'Etat Thesis, Université Paul Sabatier, Toulouse.

Lonergan, L. \& White, N. 1997. Origin of the Betic-Rif mountain belt. Tectonics, 16, 504-522.

Loomis, T. P. 1975. Tertiary mantle diapirism, orogeny, and plate tectonics east of Strait of Gibraltar. American Journal of Science, 275, 1-30.

López-Garrido, A. C. \& Sanz DE Galdeano, C. 1999. Neogene sedimentation and tectoniceustatic control of the Malaga Basin, south Spain. Journal of Petroleum Geology, 22, 81-96.
Lowe, D. R. 1982. Sediment gravity flows: II. Depositional models with special reference to the deposits of high-density turbidity currents. Journal of Sedimentary Petrology, 52, 279-297.

MAATÉ, A. 1984. Etude géologique de la couverture mésozoïque et cénozoïque des unités ghomarides au nord de Tétouan (Rif interne, Maroc). Doctorat de zème Cycle Thesis, University of Toulouse.

MAATÉ, A. 1996. Estratigrafia y evolucion palaeogeografica alpina del dominio Gomaride (Rif interno, Marruecos). Doctoral Thesis, University of Granada.

Maaté, A., Martin-Algarra, A. \& Serrano, F. 1993. El Terciario de la unidad de Saaden (Dorsal externa, Rif Septentrional, Marruecos. Geogaceta, 14, 91-93.

MacEachern, J. A. \& Burton, J. A. 2000. Firmground Zoophycos in the Lower Cretaceous Viking Formation, Alberta: a distal expression of the Glossifungites Ichnofacies. Palaios, 15, 387-398.

MARTIN-AlgARRA, A. 1987. Evolucion geologica alpina del contacto entre la zonas internas y las zonas externas de la Cordillera Betica. Doctoral Thesis, University of Granada.

Martin-Martin, M., Martin-Algarra, A. \& Serrakiel, J. 1997. El Terciario del Dominio Malaguide en Sierra Espuña (provincia de Murcia, SE España). Revista de la Sociedad Geologica de España, 10, 265-280.

Marty, R., Dunbar, R., Martin, J. B. \& BaKer, P. 1988. Late Eocene diatomite from the Peruvian coastal desert, coastal upwelling in the eastern Pacific, and Pacific circulation before the terminal Eocene event. Geology, 16, 818-822.

Meyer, R. 1987. Paléolatérites et paléosols, l'empreinte du continent dans les séries sédimentaires. Bureau de Recherches Géologiques et Minières, Manuel et Méthodes, 13.

Michard, A., Chalouan, A., Feinberg, H., Goffé, B. \& Montigny, R, 2002. How does the alpine belt end between Spain and Morocco? Bulletin de la Société Géologique de France, 173(1), 3-15.

Molina, E., Monaco, P., Nocchi, M. \& PARISI, G. 1986. Biostratigraphic correlation between the Central Subbetic (Spain) and Umbro-Marchean (Italy) pelagic sequences at the Eocene/Oligocene boundary using Foraminifera. Developments in Palaeontology and Stratigraphy, 9, 75-85.

Molina, E., Keller, G. \& Madill, M. 1988. Late Eocene to Oligocene events: Molino de Cobo, Betic Cordillera, Spain. Revista Española de Micropaleontologia, 20, 491-514.

Molina, E., Arenillas, I., Arz, J. A., Canudo, J. I., Gonzalvo, C., Ortiz, N. \& Pardo, A. 1996. Síntesis bioestratigráfica y eventos Palaeoceanográficos del Cretácico (Maastrichtiense) al Mioceno (Langhiense) basada en Foraminiferos. Revista Española de Paleontologia, (Numero Extra), $195-203$.

Morales, J., Serrano, F., Jabaloy, A., et al. 1999. Active continental subduction beneath the Betic Cordillera and the Alboran Sea. Geology, 27, $735-738$.

MORLEY, C. K. 1987. Origin of a major cross-element zone: Moroccan Rif. Geology, 15, 761-764. 
Morley, C. K. 1988. The tectonic evolution of the Zoumi Sandstones, western Moroccan Rif. Journal of the Geological Society, London, 145, 55-63.

Morley, C. K. 1992. Tectonic and sedimentary evidence for synchronous and out-of-sequence thrusting, Larache-Asilah area, Western Moroccan Rif. Journal of the Geological Society, London, 149, $39-49$.

MutTI, E. 1992. Turbidite sandstones. Agip, Special Publication, Instituto di Geologia, Milan, 1-275.

Nold, M., UtTinger, J. \& Wildi, W. 1981. Géologie de la Dorsale Calcaire ente Tétouan et Assifane (Rif Interne, Maroc). Notes et Mémoires du Service Géologique du Maroc, 300, 1-233.

Olivier, PH. 1984. Evolution de la limite entre les Zones internes et les Zones externes dans l'Arc de Gibraltar (Maroc, Espagne). Doctorat d'Etat Thesis, Université Paul Sabatier, Toulouse.

Platt, J. P. \& Vissers, R. L. M. 1989. A working hypothesis for the Alboran Sea and Gibraltar arc. Geology, 17, 540-543.

Plint, A. G. 1988. Sharp-based shoreface sequences and 'offshore bars' in the Cardium Formation of Alberta: their relationship to relative changes in sea level. In: Wilgus, C. K., Hastings, B. S., Kendall, C. G. St. C., Posamentier, H. W., Ross, C. A. \& VAN Wagoner, J. C. Sea Level Changes-An Integrated Approach. Society of Economic, Palaeontologists and Mineralogists, Society for Sedimentary Geology, Special Publications, 42, 357-370.

Pomerol, Ch. 1985. La transition Eocène-Oligocène est-elle un phénomène progressif ou brutal. Bulletin de la Société Géologique de France, 8th series, $\mathbf{I}(2), 263-367$.

Préat, A., Mamet, B., De Ridder, C., Boulvain, F. \& GILlAN, D. 2000. Iron bacterial and fungal mats, Bajocian stratotype (Mid-Jurassic, northern Normandy, France). Sedimentary Geology, 137, $107-126$.

Puglisi, D., Zaghloul, M. N. \& MaAté, A. 2001. Evidence of sedimentary supply from plutonic sources in the Oligocene-Miocene flyschs of the Rifian Chain (Morocco): provenance and palaeogeographic implications. Bollettino della Società Geologica Italiana, 120, 55-68.

Raoult, F. 1966. La chaîne du Haouz du Col d'Azlu d'Arabia au Bab Aonzar. Notes et Mémoires du Service Géologique du Maroc, 184, 61-146.

Raoult, J. F. 1974. Géologie du centre de la Chaîne Numidique (nord du Constantinois, Algérie). Mémoires de la Société Géologique de France, 121, $1-162$.

Reubert, I., Michard, A., Chalouan, A., Juteau, TH. \& JeRmoumi, B. 1982. Structure and emplacement of the Alpine-type peridotites from BéniBousera, Rif, Morocco: a polyphase tectonic interpretation. Tectonophysics, 82, 231-251.

Rivas, P., Aguirre, J. \& Braga, J. 1997. Entolium beds: hiatal shell concentrations in starved pelagic settings (middle Liassic, SE Spain). Eclogae Geologicae Helvetiae, 90, 293-301.

Roth, P. H. 1989. Ocean circulation and calcareous nannoplankton evolution during the Jurassic and
Cretaceous. Palaeogeography, Palaeoclimatology, Palaeoecology, 74, 11-126.

SaddiQi, O., Reubert, I. \& Michard, A. 1988. Sur la tectonique de dénudation du manteau infracontinental dans les Béni Bousera, Rif septentrional, Maroc. Comptes Rendus de l'Académie des Sciences, Série II, 307, 657-662.

Sanchez-Rodriguez, L. \& Gebauer, D. 2000. Mesozoic formation of pyroxenites and gabbros in the Ronda area (southern Spain), followed by early Miocene subduction metamorphism and emplacement into the middle crust: $\mathrm{U}-\mathrm{Pb}$ sensitive high-resolution microprobe dating of zircon. Tectonophysics, 316, 19-44.

Sanz de Galdeano, C., Serrano, F., Lopez Garrido, A. C. \& Martin Perez, J. A. 1993. Palaeogeography of the Late Aquitanian-Early Burdigalian Basin in the western Betic Internal zone. Geobios, 26(1), 43-55.

SAVRDA, C. E. 1995. Ichnologic applications in palaeoceanographic, palaeoclimatic, and sea-level studies. Palaios, 10, 565-577.

Savrda, C. E., Browning, J. V., Krawinkel, H. \& Hesselbo, S. P. 2001a. Firmground ichnofabrics in deep-water sequence stratigraphy, Tertiary cliniform-toe deposits, New Jersey Slope. Palaios, 16, 294-305.

Savrda, C. E., Krawinkel, H., McCarthy, M. G., McHugh, C. M. G., Olson, H. C. \& Mountain, G. $2001 b$. Ichnofabrics of a Pleistocene slope succession, New Jersey margin: relations to climate and sea-level dynamics. Palaeogeography, Palaeoclimatology, Palaeoecology, 171, 41-61.

SChlager, W. 1989. Drowning unconformities on carbonate platforms. In: CREVEllo, P. D., Wilson, J. L., Sarg, J. F. \& Read, J. F. Controls on Carbonate Platform and Basin Development. Society of Economic, Palaeontologists and Mineralogists, Society for Sedimentary Geology, Special Publications, 44, 15-25.

Serrano, F., Sanz de Galdeano, C., Delgado, F., LÓPEz-GARRIDO, A. C. \& MARTíN-ALGARRA, A. 1995. The Mesozoic and Cenozoic Complex in the Malaga area: a Palaeogene olistostrome-type chaotic complex (Betic Cordillera, Spain). Geologie en Mijnbouw, 74, 105-116.

Targuisti, K. 1994. Petrologia y geoquimica de los macizos ultramaficos de Ojen (Andalucia) y de Béni Bousera (Rif septentrional, Marruecos). Doctoral Thesis, University of Granada.

Wejuermars, R. 1987. The Palaeomares brittleductile shear zone of southern Spain. Journal of Structural Geology, 9, 139-157.

WILDI, W. 1981. Le Ferrysch: cône de sédimentation détritique en eau profonde à la bordure nordouest de l'Afrique au Jurassique moyen à supérieur (Rif externe, Maroc). Eclogae Geologicae Helveticae, 74, 481-527.

Wilson, G. S., Roberts, A. P., Verosub, K. L., Florindo, F. \& SAGnotti, L. 1998. Magnetostratigraphic chronology of the Eocene-Oligocene transition in the CIROS-1 core, Victoria Land margin, Antarctica: implications for Antarctic 
glacial history. Geological Society of America Bulletin, 110, 35-47.

Zachos, J. C., Lohmann, K. C., Walker, J. C. G. \& WISE, S. W. 1993. Abrupt climate change and transient climates during the Palaeogene: a marine perspective. Journal of Geology, 101, 191-213.
Zachos, J., Salamy, K., Quinn, T. M. \& DiesterHAASs, L. 1995. The late Eocene-early Oligocene deep-sea sediment record of continental glaciations, ocean productivity and deep water circulation and chemistry. American Geophysical Union, Spring Meeting Abstracts, 187. 